\title{
MicroRNAs at the Crossroad of the Dichotomic Pathway Cell Death vs. Stemness in Neural Somatic and Cancer Stem Cells: Implications and Therapeutic Strategies
}

\author{
Andrea Diana ${ }^{1, *,+(\mathbb{D})}$, Giuseppe Gaido ${ }^{2}$, Cristina Maxia ${ }^{1, *,+(\mathbb{D})}$ and Daniela Murtas $1, *,+(\mathbb{D}$ \\ 1 Department of Biomedical Sciences, University of Cagliari, 09042 Monserrato, Italy \\ 2 Cottolengo Mission Hospital Charia, Meru 60200, Kenya; fr.beppe@gmail.com \\ * Correspondence: diana@unica.it (A.D.); cmaxia@unica.it (C.M.); murtas@unica.it (D.M.); \\ Tel.: +39-0706754054 (A.D.) \\ + These authors contributed equally to this work.
}

Received: 4 November 2020; Accepted: 10 December 2020; Published: 17 December 2020

\begin{abstract}
Stemness and apoptosis may highlight the dichotomy between regeneration and demise in the complex pathway proceeding from ontogenesis to the end of life. In the last few years, the concept has emerged that the same microRNAs (miRNAs) can be concurrently implicated in both apoptosis-related mechanisms and cell differentiation. Whether the differentiation process gives rise to the architecture of brain areas, any long-lasting perturbation of miRNA expression can be related to the occurrence of neurodevelopmental/neuropathological conditions. Moreover, as a consequence of neural stem cell (NSC) transformation to cancer stem cells (CSCs), the fine modulation of distinct miRNAs becomes necessary. This event implies controlling the expression of pro/anti-apoptotic target genes, which is crucial for the management of neural/neural crest-derived CSCs in brain tumors, neuroblastoma, and melanoma. From a translational point of view, the current progress on the emerging miRNA-based neuropathology therapeutic applications and antitumor strategies will be disclosed and their advantages and shortcomings discussed.
\end{abstract}

Keywords: miRNA; stemness; human neural stem cell; human neural/neural crest cancer stem cell; apoptosis; cell death; brain tumors; melanoma; neurodegeneration; therapeutic target

\section{Introduction}

From a semantic point of view, stemness and apoptosis may be conceived as two different sides of the same living pathway connecting ontogenesis to cell death, swinging from regeneration to demise. In this scenario, microRNAs (miRNAs) define a class of short length (up to 23 nucleotides) noncoding single-stranded RNA molecules acting as post-transcriptional regulators of gene expression, decisive for cell differentiation, survival, function, and dysfunction [1,2]. In a previous review, we highlighted the dramatic impact of the miRNA-target regulatory network both in human normal and tumoral neural stem cells (NSCs). In physiological conditions, not more than a dozen of miRNAs alternatively operate either for promotion or repression of neural induction. Similarly, in neural cancer stem cells (CSCs), miRNAs are recruited for a double goal: tumor suppressors or oncomiRNAs (oncomiRs) for the maintenance of CSCs and homeostasis of neuronal/glial tumors [3]. miRNAs modulate neural CSC apoptosis by inhibiting the expression of one or more target genes and by decreasing the level of the related translated proteins. If compared to non-tumor NSCs, neural CSCs show a significant downregulation of pro-apoptotic miRNAs, sometimes epigenetically inactivated by hypermethylation [4]. Upon restoration, these miRNAs can inhibit anti-apoptotic target genes, 
functioning as tumor-suppressive miRNAs. On the other hand, neural CSCs are characterized by the upregulation of anti-apoptotic miRNAs, which exert their control by inhibiting pro-apoptotic target pathways. These miRNAs are then considered as oncomiRs.

Moreover, the concept has emerged that the same miRNAs can be simultaneously involved in both apoptosis-related mechanisms and cell differentiation [5]. Whether the differentiation process gives rise to the architecture of brain areas, any long-lasting perturbation of miRNA expression could be related to neuropathological events. However, while the role of miRNAs in different forms of cell death has been exhaustively elucidated with regard to several organs and cancer progression [6,7], it still represents a critical task to investigate how miRNAs orchestrate cellular removal in human neurogenesis (i.e., corticogenesis) including those major niches of stemness of the adult brain, such as within the hippocampus and in the vicinity of lateral ventricles, providing that methodological tools are able to ascertain miRNA localization.

In this review, we aim to highlight recent key studies reporting the main specific miRNAs critically involved in the modulation of signaling pathways governing the balance among survival/self-renewal, differentiation, and cell death in human NSCs and neural/neural crest-derived CSCs (Figure 1). We will also discuss how these miRNAs may be promising as targets for therapeutic strategies in patients with neuropathologies or tumors of neural/neural crest origin.

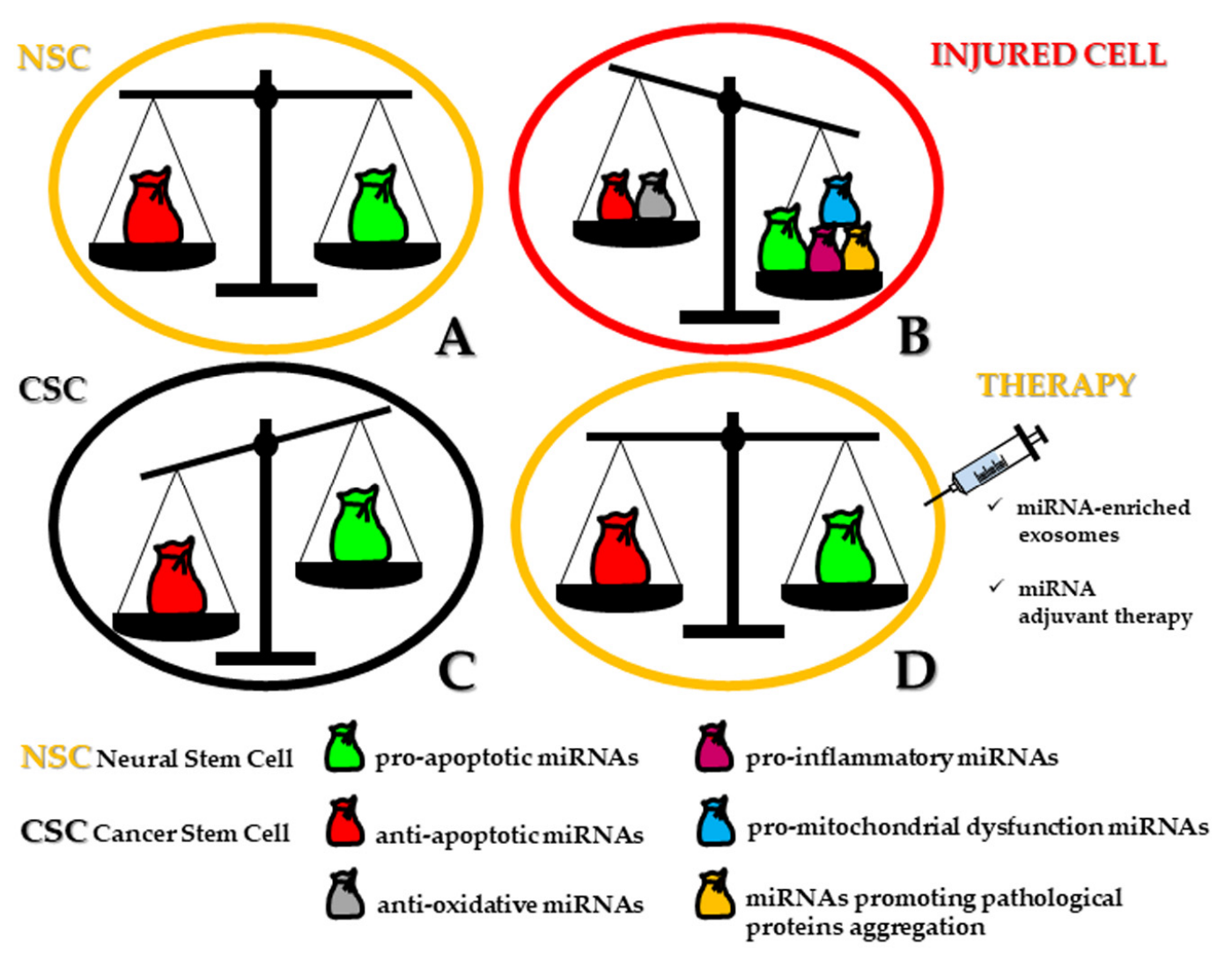

Figure 1. Contribution of different regulatory microRNAs (miRNAs) in the biology of neural stem cells (NSCs) (A), injured cells (B), cancer stem cells (CSCs) (C), and in therapy (D).

\section{2. miRNAs Bridging Stemness and Cell Death in Neurogenesis}

Until now, embryonic and adult neurogenesis seem to share only miR-7 [8,9],-9 [10-15],-124 [16-18], and -137 $[19,20]$ in the following functions: up or downregulation of proliferation, neuronal migration, axonal outgrowth/branching, neuron specification, and finally neuronal survival in the murine species (Figure 1A). Indeed, scant data are present in literature dealing with apoptosis-associated miRNAs for human neural differentiation and are obtained from human cell lines that show an association with modulated levels of miR-16, let-7a and miR-34a expression [21]. Concerning miR-34a, it has gained 
attention for the key regulatory role in neural stem/progenitor cell differentiation and various features of neurogenesis, but it is also implicated in a plethora of neurodegenerative events, such as Alzheimer's (AD) and Parkinson's (PD) disease, but also in epileptic seizures and ischemic stroke, suggesting its neuroprotective modulation especially when suppressed [22]. Interestingly, the inhibition of apoptosis in mature neurons, which is mediated by the induction of $\mathrm{Bcl}-2$ homology 3 domain (BH3)-only proteins, is exclusively dictated by miR-29 upregulation [23]. Moreover, the survival of neural progenitor cells (NPCs) under hypoxia has been found to be determined by the upregulation of miR-210 by means of suppressed Bcl-2 interacting protein 3 (BNIP3), which is an activator of cell death [24].

On the subject of oxygen and glucose requirements, human NSCs have shown their vulnerability below a certain threshold of these nutrients, but the abundant cell death appearance was reduced by miR-21 overexpression through the inhibition of c-Jun N-terminal kinase (JNK) and p38 mitogen-activated protein kinase (p38MAPK) pathways.

However, when neuronal cell death takes place in an autophagic fashion, in hippocampal NSCs, miRNA expression profiling is complicated by the integrated functions of at least seven specific miRNAs (miR-34b-5p, -138-5p, -351-5p, -503-5p, -542-5p) that are actively involved under insulin-deprived conditions. Therefore, during senescence, because of the limited replacement of dysfunctional neurons, the necessary goal of the neural network within the whole brain is attained by reversing or circumventing the apoptotic pathway, ultimately responsible for the symptomatic manifestation of various age-related diseases. On this matter, dysregulated miRNAs have been described in recent years as possible additional inducers of cellular stress and related vulnerability for neurons and, therefore, implicated in several neurodegenerative disorders [25] (Figure 1B).

It exceeds the purpose of this paper to describe the functions and potential applications of the numerous miRNAs in terms of diagnostic biomarkers since comprehensive reviews have been already written for AD [26-28] and PD [29-31], amyotrophic lateral sclerosis (ALS) [29-32], multiple sclerosis (MS) [33,34], traumatic brain injury (TBI) [35,36], or development-related syndromes, such as autism spectrum disorder (ASD) $[37,38]$. Instead, both in the central nervous system (CNS) and in the cerebral spinal fluid (CSF), miRNAs recruitment has boosted a novel impulse for the prognosis but, more strikingly, for neural regenerative medicine, shedding light on feasible translational brain applications that fill the present gap of clinical interventions represented by NSC transplantation.

\section{miRNA-Loaded Exosomes for Therapeutic Interventions in Neuropathologies}

Now, it is well established that during the formation of the neural network in the embryonic period and when neural regeneration occurs, neural cells release extracellular vesicles, also named exosomes, as an alternative intercellular communication beyond the classical synaptic neurotransmission. The decisive discovery has come from the observation that such exosomes are secreted by cortical neurons [39] and represent an efficient delivery method for integrating different miRNAs into the target neural cells [40-43]. Therefore, miRNAs have gained further attention because of their property to be inserted into mesenchymal stem cells (MSCs) or human induced pluripotent stem cells (hiPSCs) and to be released with a paracrine function or transported in order to follow an endocytic pathway [44].

MiRNA-associated exosomes display some advantages when isolated from the original cells, which can be enunciated as follows: first of all, the ability to cross the blood-brain barrier, inducing a minimal tumorigenic and immunogenic response but with a half-life longer in transplanted patients, and finally being insensitive with regard to proliferation and microvascular embolism. Collectively, exosomes, miRNAs and stem cells seem to depict the tiles of a puzzle defining the Holy Grail for therapeutic intervention.

As a matter of fact, the above properties have proposed that trio as the most promising candidate for the treatment of neurological diseases. Starting from the most challenging AD, the efficacy of treating neural degeneration has been evaluated in vivo in an amyloid $\beta$-peptide $(A \beta)$-treated rat model that was transplanted with packaged miR-29-engineered exosomes using transfected MSCs. The final result was the prevention of spatial and learning deficits typical of AD [45]. For in vitro experiments [46], 
the extracellular vesicles isolated from hiPSCs and enriched with miR-133, -155, -221 and -34a conferred neuroprotection to A $\beta 42$ oligomer-treated cortical spheroids [47,48]. With regard to remyelination strategy, which could positively impact MS, rat environmental enriched exosomes have been found to be upregulated in miR-219 content, fostering the increase in myelin but reducing the observed oxidative stress because of the dramatic consequences on the number of oligodendrocyte precursors and stem cells [49].

The therapeutic efficacy and safety of exosomes and inserted miRNAs have also been evaluated for stroke, although only a few clinical trials have been conducted in stroke patients. So far, rat stroke models and NSCs derived from different tissues have been used. Patients' plasma has been exploited for demonstrating that miR-126 is downregulated when acute ischemic stroke (AIS) occurs as well as in rat plasma and brain tissue after ischemia. Following miR-126 enrichment of adipose-derived stem cells (ADSCs)-purified exosomes, a significant reduction in neuronal cell death accompanied by a higher proliferation rate was observed. In addition, the miR-126-modified exosomes induced, in the post-stroke period, a functional recovery accompanied by a clear suppression of the inflammatory cascade [50].

Some more studies have identified in the multipotent MSCs the favorite tool for the production of miRNA-133b-bearing exosomes in rats subjected to middle cerebral artery occlusion (MCAO). In this context, the relevant contribution of astrocytes by the secretion of exosomes containing miR-133b in trophic activity for the neuronal plasticity in terms of neurite branching and elongation has been elucidated [51].

The same authors have further shown that miR-17-92 cluster-enriched exosome treatment produces a boosting effect on neurological functions by recruiting new neurons and oligodendrocytes, meanwhile determining an overall remodeling of neuronal fibers [52].

In a different experimental setting, performing administration of MSC-miR-146a-5p-exosomes, there was a confirmation of restored neurological functions, and reduced neuronal demise was associated with the inhibition of microglia in terms of M1 polarization, which accounted for the decreased expression of some pro-inflammatory mediators [53].

When NSCs were subjected to oxygen-glucose deprivation/reoxygenation for mimicking the ischemic stroke manifestation, the miR-26a exosomes from human urine-derived stem cells were able to promote both proliferation and neuronal differentiation, revealing an alternative strategy to hinder brain ischemia [54].

However, most of the available data in literature dealing with exosomes and miRNAs refer to traumatic brain and spinal cord injury (SCI). Recently, some scientists have focused on the involvement of microglial exosomes carrying miR-124-3p as cargo, whose beneficial effects were described as neuronal survival by switching M2 polarization in microglia and therefore inhibiting neuroinflammation [55]. Further evidence has been provided by showing that exosome-associated miR-124 administration increased hippocampal neurogenesis and functional recovery in the same way by silencing the Toll-like receptor 4 (TLR4) pathway [56]. In addition, the neurite outgrowth could be ascribed to microglial-derived exosomes enriched in miR-124-3p and entailing neuronal autophagy [57]. Further, repetitive mild traumatic brain injury (rmTBI) has been thought as an important risk factor for long-term neurodegenerative disorders such as $\mathrm{AD}$, where microglial exosomes have exhibited a cardinal role in the transportation, distribution, and clearance of $A \beta$. In particular, the miR-124-3p level in microglial exosomes from an injured brain was significantly changed in the acute, sub-acute, and chronic phases after rmTBI. The effects were accomplished by miR-124-3p targeting RELA proto-oncogene, NF-KB p65 subunit (RELA), an inhibitory transcription factor of apolipoprotein $\mathrm{E}$ (ApoE) that endorses $\beta$-amyloid proteolytic breakdown. In mice with rmTBI, neurons of injured brains could internalize the intravenously injected microglial exosomes and ultimately gave a robust contribution to prevent neuronal death [58].

In patients with SCI, relevant evidence for the recovery of neurological functions has been reported with regard to the positive modulation of miR-21 derived from the exosomes of MSCs [59]. This last 
finding has been also confirmed by a paper in which not only miR-21 but also miR-19b was found to be increased in extracellular vesicles from isolated MSCs and consequently were effective in apoptosis inhibition by means of downregulation of phosphatase and tensin homolog (PTEN) messenger RNA (mRNA) [60]. The mechanism by which MSC-derived exosomes carry out their neuroprotective effects on motor function and apoptosis has been found following the modulation of Fas cell surface death receptor ligand (FASL) gene axis [61].

miR-133b has been recognized as an important actor for the differentiation of neurons and the outgrowth of neurites. In this perspective, exosomes derived from miR-133b-modified MSCs have been found to induce recovery of hindlimb function after injection in rats with $\mathrm{SCI}$, by activation of the extracellular regulated kinase 1/2 (ERK1/2), signal transducer and activator of transcription 3 (STAT3), and cAMP response element-binding protein (CREB) pathways [62]. These results were replicated by a study where, in addition to the significative increase in those genes, neurofilament $(N F)$, growth associated protein 43 (GAP43), glial fibrillary acidic protein (GFAP), and myelin basic protein $(M B P)$ were also upregulated in SCI rats [63].

Exosomes from miR-29b-modified MSCs were also able to repair SCI when injected in rats with an increased score for hindlimb motor function [64].

Finally, exosomal miR-544 derived from bone marrow mesenchymal stem cells (BMSCs) mitigated neuronal functional recovery after SCI. Moreover, overexpression of miR-544 in BMSC exosomes attenuated histologic deficits and neuronal cell death induced by SCI. Remarkably, this therapeutic intervention also abated inflammatory events following SCI. In conclusion, exosomes derived from miR-544-overexpressing BMSCs improved functional recovery and promoted neuronal survival by attenuating inflammation after SCI [65].

\section{3. miRNAs Involved in the Regulation of Apoptosis in Human Neural/Neural Crest-Derived CSCs}

Along with regulating several biophysiological processes within NSCs, miRNAs are critically responsible for the control of cell fate in neural CSCs harbored in tumors of both neural and neural crest origin. These CSCs, considering the core cell subset of these tumors, express the NSC lineage markers nestin, prominin-1 (CD133), nanog homeobox (NANOG), sex determining region Y-box 2 (SOX2), hematopoietic cell E/L-selectin ligand (HCELL/CD44), octamer-binding transcription factor 4 (OCT4), bear a marked ability to form neurospheres in particular conditions [47,48], and are characterized by a tumor-initiating and self-renewal capacity through asymmetric cell division [3,66-68]. Moreover, the hallmarks of CSCs include high proliferation rate, multi-lineage differentiation potential, as well as great tendency for cell migration, invasiveness, and metastasis [69-71]. The CSC phenotype is also characterized by an enhanced resistance to apoptosis, a mechanism exploited to eliminate dysfunctional or genotoxic stress-exposed cells [4] (Figure 1C).

The tumor protein p53 (TP53) gene encodes for the key transcription factor, which coordinates cell responses to cancer-initiating insults, such as DNA damage and oncogene activation. When activated, p53 regulates the expression of a wide set of target genes promoting apoptosis, senescence, cell cycle arrest, and DNA repair [72-75]. Neural CSCs can escape apoptosis either by the downregulation of death receptors, such as death receptor 5 (DR5) and its tumor necrosis factor apoptosis inducing ligand (TRAIL), or by the overexpression of anti-apoptotic factors, such as cellular FLICE-like inhibitory protein $(c-F L I P)$, Bcl-2 apoptosis regulator (Bcl-2) family members, BMI1 proto-oncogene, polycomb ring finger (BMI-1), nuclear factor kappa-light-chain-enhancer of activated B cells (NF- $k B)$, inhibitors of apoptosis proteins (IAPs), as well as by the aberrant upregulation of phosphoinositide-3-kinase/serine-threonine protein kinase/mammalian target of rapamycin (PI3K/AKT/mTOR) signaling. The ratio between proand anti-apoptotic contents determines the balance between cell survival or cell death and modulates the susceptibility of CSCs to undergo apoptosis [76,77].

Recent in vitro and in vivo studies have shown that most neural/neural crest-derived CSCs, including brain tumor stem cells (BTSCs), glioma stem cells (GSCs), medulloblastoma (MB) as well as neuroblastoma (NB) and melanoma stem cells, are resistant to standard antitumor treatments, 
i.e., chemotherapy and radiotherapy, mainly due to high expression of anti-apoptotic genes, ATP binding cassette transporter $(\mathrm{ABC})$ family multidrug resistance transporters, and by rapid activation of DNA damage response pathways. Additionally, neural CSCs survival despite therapy and their following rapid self-renewal may result in the recurrence of the above-mentioned cancers [70,76,78-81].

Herein, we will report the miRNAs, described so far, which bear the potential to fine-tune the expression of genes intercalated in signaling networks regulating human neural/neural crest-derived CSC apoptosis, guiding the outcome of the whole tumor (Table 1). If a neural CSC is addressed to self-renewal-thus sustaining the tumor-or not critically depends on its miRNA expression profile and, ultimately, on the miRNA-targeted genes [82].

Distinct miRNAs play a key role in interfering with the apoptosis machinery by targeting p53-related genes. On the other hand, p53 itself regulates CSC properties through the modulation of miRNA expression. A cohort of miRNAs exhibits p53-dependent regulation following DNA damage. As an example, miR-34a is a component of the p53 tumor suppressor network, where miR-34a and p53 cooperate to orchestrate cell cycle and apoptosis signaling. miR-34 transactivation by p53 results in a dramatic reprogramming of gene expression, which ultimately promotes apoptosis [89,115,216-218]. Furthermore, miRNAs are able to induce drug resistance by targeting key cell cycle regulatory genes, such as cyclin-dependent kinase $6(C D K 6)$, retinoblastoma protein $(R B)$, E2 factor family of DNA-binding transcription factors (E2F), and cyclins that initiate S-phase [93].

Since miRNAs can target multiple genes and their expression pattern and function are influenced by cell- and tumor-specific environmental factors, specific miRNAs can exert opposite activities in different cancers. For this reason, the identification of differentially expressed miRNAs and their context-dependent target genes seems to be of great help in discovering the network of signaling pathways boosting specific tumors [219].

As reported in our recent review, miRNAs can act as either onco-suppressive or oncomiRs by directly regulating the commitment to apoptosis and the cell cycle progression of neural CSCs housed in brain tumors, such as glioblastoma multiforme (GBM) and MB [3].

Glioblastoma multiforme, the maximal progression stage of glioma, is the most frequent and deadliest adult CNS tumor, arising from diverse cell lineages in the adult brain, comprising NSCs, NSC-derived astrocytes, and oligodendrocyte precursor cells (OPCs), due to the dysregulation of transcriptional and epigenetic networks governing self-renewal and differentiation of these cells [136,220-222].

Medulloblastoma is the most common childhood brain tumor, originating from the aberrant proliferation of granule-cell progenitors and NSCs during development of the cerebellum $[90,223]$.

Both of these cancers are characterized by a high cellular heterogeneity, with a constitutive CD133+/CD15+ (stage specific embryonic antigen 1, SSEA-1) neural CSC subpopulation feeding the bulk tumor [71,223-225]. GSCs are the most studied neural CSCs. They are considered glioma-initiating cells and are crucial for the malignancy and recurrence of glioma. Due to their chemo- and radioresistant behavior, there is a pressing need to better understand the biology of these CSCs, so that therapy could benefit from their targeting and destruction. In the last few decades, studies investigating the dysregulated expression of miRNAs in these CSCs have shed considerable light onto the critical processes supporting the pathogenesis and progression of such malignancies [136,226-231].

Neuroblastoma is an extracranial pediatric neuroendocrine tumor, originating from embryonal or fetal neural crest stem cells, destined to become the sympathetic ganglia of the autonomic nervous system or the catecholamine-secreting cells of the adrenal glands. It is well established that epigenetic modulation, associated with developmental reprogramming errors, may drive the genesis of pediatric cancers, such as NB [232]. Its origin from pluripotent progenitors confers to NB a high level of heterogeneity and a hindrance to differentiate, which often impedes the success of antitumor therapy $[233,234]$. As other tumors, NB houses a CSC population, responsible for its aggressive nature [163]. Some miRNAs have been demonstrated to be differentially expressed in NB CSCs, with miRNA profiles being strongly associated with apoptosis management $[112,212,234]$. 
Table 1. Pro- and anti-apoptotic miRNAs associated with apoptosis regulation in CSCs of neural/neural crest origin.

\begin{tabular}{|c|c|c|c|c|c|}
\hline miRNA & Target mRNA/Pathway & miRNA Effect on Apoptosis & miRNA Expression in CSCs & Cancer Type & Ref. \\
\hline miR-7 & EGFR, AKT, DR5 & $\uparrow$ & down & glioma & [83] \\
\hline $\mathrm{miR}-23 \mathrm{~b}$ & HMGA2 & $\uparrow$ & down & glioma & [84] \\
\hline miR-26a & SODDs & $\uparrow$ & down & melanoma & {$[85,86]$} \\
\hline miR-29a & QKI-6 & $\uparrow$ & down & glioma & {$[87,88]$} \\
\hline \multirow[t]{2}{*}{$\mathrm{miR}-34 \mathrm{a}$} & BCL2, TP53, NOTCH1/NOTCH2, Dll1, RICTOR, AKT, Wnt/B-catenin & $\uparrow$ & down & glioma, MB & [89-92] \\
\hline & TP53, NOTCH & $\uparrow$ & down & melanoma & {$[79,93-95]$} \\
\hline miR-107 & NOTCH2, MMP-12 & $\uparrow$ & down & glioma & [96] \\
\hline miR-124 & $C D K 6, R B$ & $\uparrow$ & down & glioma & {$[4,97]$} \\
\hline \multirow[t]{2}{*}{ miR-137 } & $C D K 6, R B, G L I P R$ & $\uparrow$ & down & glioma & {$[4,97-99]$} \\
\hline & CTBP1, PIK3R3 & $\uparrow$ & down & melanoma & [100-102] \\
\hline miR-125a-5p & LIN28B & $\uparrow$ & down & melanoma & {$[103,104]$} \\
\hline \multirow[t]{4}{*}{$\mathrm{miR}-125 \mathrm{~b}$} & $C D K 6, C D C 25 A$ & $\uparrow$ & down & glioma & [105-108] \\
\hline & TNFAIP3, NKIRAS2, TP53, p38MAPK, BAK1 & $\downarrow$ & up & glioma & [109-111] \\
\hline & TP53 & $\downarrow$ & up & NB & {$[112,113]$} \\
\hline & NEDD9 & $\downarrow$ & up & melanoma & [114] \\
\hline miR-128 & EGFR/PDGFR/AKT, BMI-1 & $\uparrow$ & down & glioma & {$[105,115-117]$} \\
\hline miR-218 & CDK6, MKI67, ECOP & $\uparrow$ & down & glioma & {$[108,118-120]$} \\
\hline miR-129-5p & $F N D C 3 B$ & $\uparrow$ & down & glioma & [121] \\
\hline miR-134 & NANOG & $\uparrow$ & down & glioma & [122] \\
\hline miR-138 & $H I F 1 \alpha$ & $\uparrow$ & down & melanoma & [123] \\
\hline miR-141 & $J A G 1$ & $\uparrow$ & down & glioma & [124] \\
\hline miR-145 & BNIP3, NOTCH, SOX9, ADD3 & $\uparrow$ & down & glioma & [125-127] \\
\hline miR-146b-5p & $H u R$ & $\uparrow$ & down & glioma & [128] \\
\hline miR-149 & $B C L 2, C D C 42$ & $\uparrow$ & down & NB & [129] \\
\hline miR-152/153 & KLF4, LGALS3 & $\uparrow$ & down & glioma & {$[105,130-132]$} \\
\hline miR-181 & NOTCH2 & $\uparrow$ & down & glioma & {$[133,134]$} \\
\hline miR-182 & $B C L 2 L 12, c-M E T, H I F 2 \alpha$ & $\uparrow$ & down & glioma & [135] \\
\hline miR-199b-5p & HES1 & $\uparrow$ & down & $\mathrm{MB}$ & {$[117,136]$} \\
\hline $\mathrm{miR}-200 \mathrm{~b}$ & CD133 & $\uparrow$ & down & glioma & [137] \\
\hline miR-203 & PLD2 & $\uparrow$ & down & glioma & [138] \\
\hline \multirow[t]{2}{*}{ miR-211 } & $M M P-9, B C L 2$ & $\uparrow$ & down & glioma & [139] \\
\hline & KCNMA1 & $\uparrow$ & down & melanoma & [140-143] \\
\hline miR-218 & CIP2A, BMI-1 & $\uparrow$ & down & melanoma & {$[102,144]$} \\
\hline miR-219-5p & $B C L 2$ & $\uparrow$ & down & melanoma & [145] \\
\hline miR 302-367 & CXCR4, CXCL12 & $\uparrow$ & down & glioma & [146] \\
\hline miR-326 & NOTCH, SMO, GLI1 & $\uparrow$ & down & glioma, MB & {$[108,117,147-150]$} \\
\hline $\mathrm{miR}-340$ & ROCK1 & $\uparrow$ & down & glioma & [151] \\
\hline miR-451 & $A K T 1, C C N D 1, M M P-2, M M P-9, B C L 2, C A B 39$ & $\uparrow$ & down & glioma & [152-154] \\
\hline $\mathrm{miR}-503$ & IGF-1R/PI3K/AKT & $\uparrow$ & down & glioma & [155] \\
\hline miR-608 & $M I F$ & $\uparrow$ & down & glioma & {$[3,156]$} \\
\hline miR-625 & SOX2 & $\uparrow$ & down & melanoma & {$[104,157]$} \\
\hline
\end{tabular}


Table 1. Cont.

\begin{tabular}{|c|c|c|c|c|c|}
\hline miRNA & Target mRNA/Pathway & miRNA Effect on Apoptosis & miRNA Expression in CSCs & Cancer Type & Ref. \\
\hline miR-873 & IGF2BP1 & $\uparrow$ & down & glioma & [158] \\
\hline \multirow[t]{2}{*}{ let-7 } & KRAS, PI3K/AKT, MAPK/ERK, LIN28/let-7/c-MYC, NEAT1 & $\uparrow$ & down & glioma, MB & [159-162] \\
\hline & $M Y C N$ & $\uparrow$ & down & NB & {$[163,164]$} \\
\hline miR-9 & PTCH1 & $\downarrow$ & up & glioma & {$[71,165-167]$} \\
\hline miR-9* & SOX2 & $\uparrow$ & down & glioma & {$[165,168]$} \\
\hline miR-10b & MBNL1-3, SART3, RSRC1 & $\downarrow$ & up & glioma & {$[3,108,169,170]$} \\
\hline \multirow[t]{2}{*}{ miR-21 } & FASL, TP53, TGF- $\beta, P T E N$, PDCD4, TIMP3 & $\downarrow$ & up & glioma & {$[3,87,134,171-174]$} \\
\hline & TIMP3 & $\downarrow$ & up & melanoma & {$[140,175-177]$} \\
\hline miR-24 & $S T 7 L, \beta$-catenin $/ T C F-4$ & $\downarrow$ & up & glioma & [178] \\
\hline $\mathrm{miR}-27 \mathrm{~b}$ & $\beta$-catenin/TCF-4 & $\downarrow$ & up & glioma & [179] \\
\hline miR-30 & SOCS3, JAK/STAT3 & $\downarrow$ & up & glioma & {$[150,180]$} \\
\hline miR-17-92 & PTEN, PI3K/AKT & $\downarrow$ & up & glioma & {$[3,132,134,181,182$} \\
\hline miR-92b & SMAD3, TGF- $\beta / P 21$ & $\downarrow$ & up & glioma & [183] \\
\hline miR-138 & BLCAP, CASP3, BTG2, TUSC2 & $\downarrow$ & up & glioma & {$[126,184]$} \\
\hline miR-149 & CASP2 & $\downarrow$ & up & glioma & {$[185,186]$} \\
\hline miR-155 & PTEN, CASP3, CASP9, PIЗK/AKT, CDX1, SIX1 & $\downarrow$ & up & glioma & {$[3,187,188]$} \\
\hline miR-182 & FOXO3, MITF & $\downarrow$ & up & melanoma & {$[140,189-191]$} \\
\hline miR-196a & $I \kappa B \alpha$ & $\downarrow$ & up & glioma & [192] \\
\hline miR-196a-5p & FOXO1 & $\downarrow$ & up & glioma & [193] \\
\hline miR-211-5p & CHOP, IGF-2R & $\downarrow$ & up & melanoma & [194,195] \\
\hline $\mathrm{miR}-210$ & $M N T, H I F 1 \alpha / \mathrm{miR}-210 / G P D 1 L, R O D 1$ & $\downarrow$ & up & glioma & {$[186,196-198]$} \\
\hline \multirow[t]{2}{*}{$\mathrm{miR}-221 / 222$} & P27, P57, PUMA & $\downarrow$ & up & glioma & [199-202] \\
\hline & C-KIT, ETS-1, P27 & $\downarrow$ & up & melanoma & {$[140,203-207]$} \\
\hline \multirow{2}{*}{$\begin{array}{c}\text { miR-330,-363, } \\
-582-5 \mathrm{p} \\
\text { miR-335 }\end{array}$} & CASP3, CASP9, BIM & $\downarrow$ & up & glioma & {$[87,208]$} \\
\hline & DAAM1, PAX6 & $\downarrow$ & up & glioma & [209-211] \\
\hline miR-380-5p & TP53, HRAS & $\downarrow$ & up & NB & {$[212,213]$} \\
\hline $\mathrm{miR}-638$ & TP53INP2 & $\downarrow$ & up & melanoma & [214] \\
\hline miR-130b & MST1/2, SAV1, Hippo pathway & $\downarrow$ & up & glioma & [215] \\
\hline
\end{tabular}

$\uparrow$ pro-apoptotic; $\downarrow$ anti-apoptotic; down: downregulated; up: upregulated; MB: medulloblastoma; NB: neuroblastoma. 
Melanoma is a highly aggressive and deadly neuroectodermal tumor developing by the malignant transformation of neural crest-derived melanocytes. Due to its frequency and aggressiveness, it represents the most thoroughly studied neural crest-derived cancer [235]. In the bulge area of dermal hair follicles, a source of melanocyte stem cells (MCSCs) has been localized, which, if genetically or epigenetically altered, can proliferate and migrate abnormally, acting as melanoma cells of origin in the skin and resulting in melanomagenesis $[236,237]$. Melanoma harbors high cell heterogeneity including multi-subpopulations of cancer cells, some of which, due to their stemness features, are identified as melanoma stem cells and can be detected by the neural cell surface marker CD133, as well as by the neuroectodermal internal marker nestin [71,79,238-241].

\subsection{Pro-Apoptotic miRNAs}

Diverse miRNAs with pro-apoptotic function have been identified so far and their downregulation in neural/neural crest CSCs has been described as a factor promoting tumorigenesis.

miR-7 expression is significantly diminished in GSCs, which grants such cells strong resistance to apoptosis. However, by engineering a panel of GSCs to express miR-7, the role of this miRNA in targeting the apoptotic pathways in GSCs has been revealed, by means of downregulated expression of epidermal growth factor receptor (EGFR), suppressed AKT signaling activation, and upregulated DR5; thus, sensitizing GSCs to TRAIL-mediated apoptosis [83].

miR-23b is epigenetically silenced by hypermethylation in U87 GSCs, where the apoptotic machinery results in being suppressed. When this cell subpopulation is transfected with miR-23b mimics, it downregulates its target gene high mobility group AT-hook 2 (HMGA2) and, meanwhile, sensitizes U87 GSCs to temozolomide (TMZ)-induced apoptosis [84].

miR-26a is significantly downregulated in A375 melanoma stem-like cells, which endow a subpopulation with CSC-like traits, characterized by the ability to form melanospheres [203,242]. This miRNA has been shown to induce apoptosis in A375 cells by directly targeting the silencer of death domains $(S O D D s)$ gene, which has a pivotal role in halting apoptosis in sensitive melanoma cell lines $[85,86]$.

miR-29a is also reduced in CD133+ GSCs, allowing GSCs to have continuous activation of survival-promoting pathways. When ectopically expressed, miR29a targets Quaking gene isoform 6 (QKI-6), which leads to the Wilms tumor protein 1 (WT1)-mediated repression of key pro-survival target genes, such as EGFR [87]. Moreover, miR-29a overexpression sensitizes CD133+ GSCs to cisplatin-induced apoptosis [88].

miR-34a is downregulated in GSCs and MB CSCs, resulting in increased cell survival and reduced CSC differentiation [91]. Conversely, miR-34a experimental induction in U87 GSCs inhibits the expression of the Bcl-2 as well as the Notch receptor 1/2 (NOTCH1/NOTCH2) and Notch ligand Delta-like 1 (Dll1) genes, boosting apoptosis and cell differentiation. According to cell cycle analysis, ectopic miR-34a expression induces cell cycle arrest in G1 phase [3,90,92,105]. In HNGC-2 and NSG-K16 GSCs, restored miR-34a functionally targets the rapamycin-insensitive companion of mTOR (RICTOR) gene, a defining component of the mammalian target of rapamycin complex 2 (mTORC2); thus, suppressing the AKT and wingless-related integration site $(\mathrm{Wnt}) / \beta$-catenin signaling pathways and reducing the levels of the Wnt pathway-target proteins cyclin D1 (CCND1) and myc proto-oncogene (c-MYC) [219].

In A375 melanoma stem-like cells, miR-34a expression is silenced by aberrant methylation of its promoter, which can provide a selective benefit for tumor cells by suppressing the p53 machinery and activating the Notch signaling. However, miR-34 expression is restored after etoposide treatment, which results in increased apoptosis and cell cycle arrest, thereby recovering the effect of p53. Thus, these findings may explain, at least in part, the anti-proliferative effect of miR-34a in melanoma stem-like cells $[79,93-95]$. 
miR-107 expression is diminished in GSCs. When re-expressed, this miRNA functions as a tumor suppressor gene and inhibits CD133+ GSCs proliferation by targeting the NOTCH2 and matrix metalloproteinase-12 (MMP-12) mRNA expression [96].

miR-124 and miR-137, simultaneously lost along gliomagenesis, when restored, induce G0/G1 cell cycle arrest of GSCs, in association with decreased expression of CDK6 and phosphorylated RB (pSer 807/811) proteins $[4,97,98,100,105]$. miR-137 also downregulates the mRNA and protein level of glioma pathogenesis-related protein (GLIPR), also known as related to testis-specific, vespid, and pathogenesis proteins 1 (RTVP-1), in GSCs; thus, rescuing cell responsiveness to apoptotic effects [99].

miR-137, located at a melanoma hotspot in the human genome, is significantly decreased in A375 melanoma stem-like cells. It can act as a tumor suppressor by directly targeting C-terminal binding protein 1 (CTBP1), inhibiting epithelial-to-mesenchymal transition (EMT) and inducing apoptosis [100]. In these cells, miR-137 has also been shown to be a negative regulator of phosphatidylinositol-3-kinase regulatory subunit 3 (PIK3R3), a transducer of intracellular lipid substrates that is involved in the regulation of apoptosis [101,102].

miR-125a-5p is downregulated in A375 melanoma stem-like cells. Although this condition accelerates cell growth in vitro, when re-expressed, miR-125a-5p functions as a tumor suppressor by directly targeting lin-28 homolog B (LIN28B), which serves as its functional effector. Furthermore, the involvement of a let-7-dependent mechanism downstream of LIN28B has been demonstrated, which results in the activation of the transforming growth factor- $\beta$ (TGF- $\beta$ ) signaling cascade $[103,104,140]$.

miR-125b is amongst the first miRNAs described as downregulated in human U251 GSCs, with a pivotal role in GSC maintenance. In CD133+ GSCs, the downregulation of miR-125b leads to E2F transcription factor 2 (E2F2) expression and cell cycle progression. When its functionality is restored, miR-125b suppresses the expression of cell cycle regulatory proteins CDK6, a G1/S cell cycle regulator, and cell division cycle 25A (CDC25A), thereby inducing cell cycle arrest at the G1/S checkpoint [105-108]. Nonetheless, emerging evidence has further demonstrated that miR-125b can be overexpressed in GSCs, where it targets tumor necrosis factor alpha-induced protein 3 (TNFAIP3) and NF- $\mathrm{kB}$ inhibitor interacting Ras-like 2 (NKIRAS2), TP53, p38MAPK, resulting in increased NF- $\mathrm{kB}$ expression, anti-apoptotic activity, and upregulation of cell cycle genes [109]. This relates to the resistance of GSCs to tumor necrosis factor alpha (TNF $\alpha$ )- and TMZ-induced apoptosis; thus, classifying miR-125b as a predictor of TMZ response in GBM patients. Similarly, miR-125b enhances TMZ resistance by targeting Bcl-2 antagonist/killer 1 (BAK1) [110]. The repression of miR125b before TMZ treatment improves the chemosensitivity of GSCs to TMZ and thus results in inhibition of cell proliferation and increased apoptosis [111]. The double function of miR-125b in tumor regulation indicates that it may act as a potent tumor promoter or inhibitor depending on the different molecular context. Considering that a miRNA can target more than one gene, it would be deduced that the panel of genes that predominantly contribute to the phenotypes prompted by the miRNA may depend on the cell microenvironment. In this context, further studies will hopefully elucidate the dual role of miR-125b, supporting its value as therapeutic target.

In NB, the knowledge regarding the expression of tumor suppressive miRNAs or oncomiRs in CSCs is still limited. One of the few reported studies has shown that miR-125b may act as an oncogene in N-type SH-SY5Y human NB cells, which have many similarities to CSCs, such as the expression of the neuroectodermal stem cell intermediate filament nestin and the capacity to form colonies in soft agar [243-245]. Overexpression of miR-125b is a negative regulator of TP53 and p53-induced apoptosis in NB cells. Conversely, knockdown of miR-125b has been demonstrated to retrieve the level of p53 protein and induce apoptosis [112,113].

In A375 melanoma stem-like cells, miRNA expression profiling has shown an overexpression of miR-125b, -100, and -199-5p, while miR-513a-5p and -185 are underexpressed, with miR-125b being considered as the determinant candidate of melanoma progression, through its ability to target the neural precursor cell expressed, developmentally down-regulated 9 (NEDD9) gene [114]. 
miR-128 is remarkably reduced in CD133+ GSCs, favoring GSC maintenance and tumor growth. However, upon re-expression, it represses GSCs' growth, mediates their differentiation, and exerts a pro-apoptotic role by downregulating the oncogenic EGFR/platelet-derived growth factor receptor/AKT (EGFR/PDGFR/AKT) pathway and BMI-1, a factor critical for an efficient self-renewing division of GSCs $[105,115-117]$.

BMI-1 is also targeted by the onco-suppressor miR-218, commonly downregulated in GSCs $[3,105,108,118]$. The mechanisms by which exogenous administration of miR-218 rescues apoptosis in U87 GSCs also includes the functional targeting of $C D K 6$, marker of proliferation Ki-67 (MKI67), and epidermal growth factor receptor-coamplified and overexpressed protein (ECOP), which affects NF- $\mathrm{kB}$ activity and the associated apoptotic response $[119,120]$.

miR-129-5p expression is downregulated in U87 and U251 GSCs, with fibronectin type III domain containing 3B (FNDC3B) as a target gene. U87 cells transfected with miR-129-5p mimics and FNDC3B short hairpin RNAs (shRNAs) exhibit restored cell apoptosis, corroborating the tumor-suppressing role of miR-129-5p [121].

miR-134 expression is lost in BTSCs and in sphere-forming U87 GSCs, causing inhibition of apoptosis and uncontrolled cell proliferation. Conversely, its ectopic expression promotes apoptosis and cell differentiation by regulating NANOG as the main target, at the mRNA and protein level [122].

miR-138 expression level is downregulated in A375 melanoma cells. When ectopically overexpressed, it increases apoptosis and inhibits cell proliferation and metastasis by directly targeting the degradation of hypoxia-inducible factor- 1 alpha $(H I F 1 \alpha)$. Therefore, it functions as a suppressor of melanoma occurrence and development [123].

miR-141 expression levels are greatly reduced into the CD133+ GSC subpopulation, conferring resistance to apoptosis. However, following overexpression in GSCs, miR-141 can inhibit the jagged canonical Notch ligand 1 (JAG1) and thus restoring the expression of apoptosis-related genes [124].

miR-145 is expressed at very low levels in GSCs, which is associated with increased tumorigenesis. Though, when experimentally induced, it increases U87 GSC apoptosis by inhibiting BNIP3 and Notch signaling $[125,126]$. Moreover, targeting of SRY-box transcription factor 9 (SOX9) and adducin 3 (ADD3) by miR-145 has been reported, consistent with increased apoptosis [127].

In melanoma cell lines, miR-145 has been proposed as a miRNA whose reduced expression implies the acquisition of a stem-like phenotype, defined by the ability to grow non-adherently as melanospheres in vitro $[115,246]$.

miR-146b-5p expression is lowered in gliomagenesis. However, miR-146b-5p overexpression, by suppressing Hu antigen $\mathrm{R}(H u R)$ expression, increases apoptosis and radiosensitivity, and induces differentiation in GSCs [128].

miR-149 underexpression has been demonstrated in SK-N-BE(2)-C and SK-N-SH NB stem-like cells and in NB tissues, and is associated with poor survival rates. However, transfection of these cells with miR-149 re-establishes its pro-apoptotic and anti-proliferative function by targeting Bcl-2 and cell division cycle 42 (CDC42). Furthermore, introduction of miR-149 increases chemosensitivity to doxorubicin (DOX) in NB cells [129].

miR-152 and -153 expression levels are reduced in cultured CD133+ GSCs and are critically involved in glioma tumor growth. Re-expression of these two miRNAs reduces cell proliferation and induces differentiation and apoptosis by downregulating the transcription factor Krüppel-like factor 4 (KLF4), inhibiting the expression of galectin 3 (LGALS3), and indirectly attenuating the activation of mitogen-activated protein kinase kinase 1/2 (MEK1/2) and PI3K signaling pathways [3,105,130-132].

Reduced miR-181 expression in GSCs has been demonstrated to upregulate CD133 expression and the downstream signaling pathways. Instead, restoration of miR-181, by targeting the NOTCH2 receptor gene, downregulates CD133 and retrieves cell apoptosis [133]. Moreover, transient overexpression of miR-181a in U87 GSCs significantly sensitizes these cells to radiation treatment, concurrently with downregulation of the Bcl-2 protein [134]. 
Endogenous miR-182 levels are decreased in U87 GSCs, leading to GBM growth, hypoxia-induced dedifferentiation, and tumor progression. However, ectopic expression of miR-182 negatively regulates the oncogenic signature, including Bcl-2 family protein Bcl-2-like protein 12 (BCL2L12), MET proto-oncogene, receptor tyrosine kinase (c-MET), and hypoxia-inducible factor-2 alpha (HIF2 $\alpha$ ). Conversely, miR-96 and miR-183, also belonging to the 183-96-182 miR cluster, fail to crack down on the oncogene BCL2L12 expression, which is able to neutralize effector caspases and p53 activation. Moreover, miR-182 sensitizes glioma cells to therapy-induced apoptosis [135].

In CD15+/CD133+ MB cells, expression of miR-199b-5p is downregulated by class B basic helix-loop-helix protein 39 (HES1) overexpression, with a negative feedback regulation, and by methylation of the cytosine-phosphate-guanine $(\mathrm{CpG})$ island upstream of its promoter region. On the other hand, when overexpressed, miR-199b-5p can reduce the subpopulation of MB CSCs and induce cell differentiation, with HES1 as a target gene involved in both the canonical Notch and noncanonical sonic hedgehog $(\mathrm{SHH})$ pathways $[117,224]$.

miR-200b, a member of the miR-200 family, is significantly decreased in glioma U251 cells. Cell transfection with miR-200b mimics, on the contrary, results in decreased expression of CD133 mRNA and restored cell apoptosis [137].

Downregulation of miR-203, as a tumor suppressor, is responsible for the maintenance of stem properties of CD133+ GSCs. When re-expressed, miR-203 can retrieve apoptosis by directly repressing its target phospholipase D2 (PLD2) [138].

On the contrary, miR-203 has been shown to be overexpressed in melanospheres derived from D10 and A375 melanoma stem-like cells, displaying its dual effect observed in several cancers. In these cells, miR-203 enhances the number and size of colonies and leads to the upregulation of SOX2, KLF4, and OCT4, as main transcription factors in the management of pluripotency [247].

miR-211 is greatly decreased in GSCs by aberrant hypermethylation of its promoter region. After rescuing its expression, miR-211 downregulates the expression of matrix metalloproteinase-9 (MMP-9) and anti-apoptotic proteins, such as Bcl-2. At the same time, the levels of cell cycle inhibitors, such as p53, and the proteolytic activity of caspase-9 (CASP9), increase; thus, triggering the mitochondrial/caspase-3 (CASP3)/CASP9-mediated apoptotic pathway [139].

Another target of miR-211 is potassium calcium-activated channel subfamily Malpha 1 (KCNMA1), overexpressed in A375 melanoma stem-like cells due to the endogenous low levels of miR-211. When this miRNA is ectopically expressed, these cells face significant growth inhibition, compared with the respective parental melanoma cell lines [140-143].

miR-218 is a tumor suppressive miRNA decreased in A375 melanoma stem-like cells, while the transfection of these cells with this miRNA mimic has been shown to cause cell cycle arrest in the G0/G1 phase, by targeting cellular inhibitor of PP2A (CIP2A) and BMI-1, supporting the hypothesis of the pivotal role of miR-218 in melanoma development [102,144].

miR-219-5p is downregulated in A375 melanoma stem-like cells, negatively correlating with Bcl-2 protein levels. In these cells, the transfection of miR-219-5p restores intrinsic apoptosis by suppressing the antiapoptotic gene $\mathrm{Bcl}-2$ and increasing cleaved CASP3 and CASP9 levels. Thus, the upregulation of miR-219-5p inhibits melanoma growth and metastasis and strengthens melanoma cells' chemosensitivity [145].

The miR302-367 cluster is undetectable in glioma-initiating cell lines. However, during serum-mediated stemness suppression, its induced expression leads to a drastic downregulation of C-X-C motif chemokine receptor 4 (CXCR4) and its ligand C-X-C motif chemokine ligand 12 (CXCL12), which impairs the stemness characteristics and induces differentiation of GSCs [146].

miR-326 is downregulated, via decreased expression of its host gene, in GSCs and in D283 Med CSCs. Transfection of miR-326 into GSCs can rescue its functionality, inhibiting the Notch signaling pathway and impairing cell proliferation rate. NOTCH, in turn, is able to suppress miR-326, establishing a regulatory feedback loop. The NOTCH/miR-326 axis in GSCs is shifted towards high NOTCH and low miR-326 activity, but it can be reversed by miR-326 transfection $[108,117,147]$. 
Moreover, miR-326 ectopic expression represses smoothened, frizzled class receptor (SMO) and its downstream gene glioma-associated oncogene homolog 1 (zinc finger protein) (GLI1), which is no longer able to translocate into the nucleus and to regulate its target genes' transcription [148-150].

miR-340 is decreased in U87 and U251 GSCs, triggering GBM development. Conversely, reintroduction of miR-340 leads to inhibition of cell proliferation and induction of apoptosis by directly targeting Rho associated coiled-coil containing protein kinase 1 (ROCK1) [151].

Expression of miR-451 has been found to be significantly reduced in U251 GSCs, impacting their survival and proliferation rate. On the contrary, administration of miR-451 mimic oligonucleotides results in G0/G1 phase cell cycle arrest and increased apoptosis, through AKT1, CCND1, matrix metalloproteinase-2 (MMP-2), MMP-9, and Bcl-2 reduction, and increase in cyclin-dependent kinase inhibitor $1 \mathrm{~B}\left(C D K N 1 B / P 27^{K I P 1}\right)$ expression. Further evidence has suggested that the regulation of miR-451 by the mothers against decapentaplegic homolog (SMAD) protein, when transfected in GSCs, inhibits cell growth, likely by the upregulation of miR-451 [152,153]. Moreover, miR-451 represses U251 GSC proliferation and induces apoptosis, by regulating calcium binding protein 39 (CAB39) as a direct target and indirectly inhibiting the PI3K/AKT pathway [154].

miR-503 is also subject to downregulation in U87 and U251 GSCs, a condition that prompts cell proliferation. When ectopically induced, miR-503 triggers apoptosis and leads to G0/G1 cell cycle arrest, by negatively regulating insulin-like growth factor-1 receptor (IGF-1R) and consequently weakening the functionality of the IGF-1R/PI3K/AKT signaling pathway, a core pathway in GBM oncogenesis [155].

Downregulation of miR-608 has been recently linked to an increase in the macrophage migration inhibitory factor (MIF) gene and protein in GSCs. On the contrary, restored miR-608 expression negatively regulates the expression of MIF and induces apoptosis in GSCs [3,156].

Expression level of miR-625 is significantly low in A375 melanoma cells, although it can be recovered upon cell transfection with miR-625 mimics, which results in enhanced apoptosis and inhibited cell growth, by the silencing of the transcription factor SOX2 $[104,157]$.

miR-873 is expressed at low levels in U87 GSCs, playing a pivotal role in GBM development. Restoration of miR-873 inhibits cell proliferation and induces apoptosis, by directly knocking down insulin-like growth factor 2 MRNA binding protein 1 (IGF2BP1) expression [158].

let-7 (lethal-7) miRNA family is classified as tumor suppressive, since its members attenuate cancer aggressiveness, chemo- and radioresistance, but they result significantly reduced in GBM and MB CSCs [159-162]. Forced expression of let-7a can silence Kirsten rat sarcoma viral oncogene homolog (KRAS) and its downstream pathways PI3K/AKT and mitogen-activated protein kinase (MAPK)/ERK, inducing apoptosis in GSCs. Indeed, among the many oncogenes and miRNAs identified as regulators of cell growth/proliferation/apoptosis, MYC and let-7a have emerged as the respective key oncogene and miRNA deregulated in GSCs. let-7a has been shown to be part of the lin-28 homolog A (LIN28)/let-7/c-MYC triad, controlled by double-negative autoregulatory loops (LIN28/let-7 and Myc/let-7), which play a critical role in controlling apoptosis [248]. LIN28 is a master regulator of pluripotency in embryonic stem cells (ESCs). In association with NANOG, OCT4, and SOX2, it is able to reprogram differentiated cells to pluripotent stem cells [249]. Moreover, let-7e suppresses the expression of nuclear paraspeckle assembly transcript 1 (NEAT1), a long non-coding RNA (lncRNA) that leads to enhanced apoptosis in U87 and U251 GSCs [160]. However, in uncommon situations, let-7 can act as an oncogene, reducing mitochondrial apoptosis and increasing cell proliferation, chemoresistance, tumor progression and metastasis [162]. Inhibition of let-7a-3p in U87 and U251 GSCs has been demonstrated to partly recover mitochondrial apoptosis induced by neurotensin receptor 1 (NTSR1) inhibition, along with downregulation of Bcl-2-like protein 2 (Bcl-w) and Bcl-2 [250]. The dual/two-faced behavior of let-7 indicates that its function may depend on specific target transcripts. Thus, further research studies are required to focus on the specific biological context of let-7 expression and its role in GSCs.

let-7a miRNA also acts as a tumor suppressor in NB by inhibiting oncogene transcription and stemness features of tumor cells [164]. It has been found to be downregulated in N- and I-type NB 
cell lines [243-245], likely due to its negative regulation by the neural crest-directed expression of LIN28 [251]. Therefore, difluoromethylornithine (DFMO) treatment on SMS-KCNR and BE(2)-C stem-like cells, characterized by V-Myc avian myelocytomatosis viral oncogene neuroblastoma (MYCN) amplification, reduces LIN28 and MYCN protein levels; thus, restoring let-7 miRNA expression and decreasing neurosphere formation $[163,164]$.

\subsection{Anti-Apoptotic miRNAs}

Several miRNAs with anti-apoptotic function are upregulated in neural/neural crest CSCs. By controlling multiple target mRNAs, they suppress apoptotic pathways and ultimately preserve stem cell self-renewal and pluripotency.

In CD133+ GSCs, miR-9 is upregulated, negatively controlling the tumor suppressor gene Patched 1 (PTCH1) and resulting in diminished cell death. Moreover, miR-9 has been found to induce upregulation of the ATP binding cassette subfamily B member 1 ( $A B C B 1$ ) gene, leading to chemoresistance to TMZ. Knockdown of miR-9, instead, restores TMZ-induced cell death. In contrast, miR-9* (miR-9-3p) is downregulated in GSCs, although, when re-expressed, it can inhibit SOX2, a factor that confers self-renewal ability and drug resistance to GSCs [70,165-168].

miR-10b is upregulated in GSC lines, acting as a tumor promoter. Specifically, it has been reported to sustain cell stemness and affect the cell cycle, by targeting muscleblind-like splicing regulator 1 (MBNL1-3), spliceosome associated factor 3, U4/U6 recycling protein (SART3), arginine and serine rich coiled-coil 1 (RSRC1), and genes associated with RNA processing and splicing, according to Gene Set Enrichment Analysis (GSEA) [169,170]. Treatment with miR-10b inhibitors (anti-miR-10b) strongly impairs survival and proliferation and attenuates expression of stem cell markers nestin and OCT4. Moreover, miR-10b inhibition leads to the cleavage of CASP3 and CASP7, indicative of the induction of apoptotic cell death in GSCs [3,108,170].

Several studies have described miR-21 as one of the most consistently highly expressed oncomiRs in GBM, where it regulates multiple stemness parameters. Suppression of apoptosis is one of the key roles of miR-21. In GSCs, miR-21 confers resistance to apoptosis by targeting the FASL as well as by inhibiting an entire network of onco-suppressor genes, including TP53, TGF- $\beta, P T E N$, and programmed cell death 4 (PDCD4). Moreover, the high levels of miR-21 in U87 GSCs are able to prevent glioma cell apoptosis by inhibiting the tissue inhibitor of metalloproteinases 3 (TIMP3) gene, a suppressor of malignancy and inhibitor of matrix metalloproteinases (MMPs) [171]. Thus, inhibition of miR-21, by locked nucleic acid (LNA) or by anti-miR oligonucleotides, can not only restore apoptosis by activation of the caspase cascade via a FAS-dependent or PDCD4-mediated mechanism, but also stops cell cycle progression by decreasing EGFR/STAT3 signaling, and finally sensitizes GSCs to TMZ chemotherapy or radiation treatment $[3,87,134,172-174]$.

Similarly, miR-21 has been found overexpressed in A375 melanoma stem-like cells, affecting cell apoptosis by targeting TIMP3 [140,175-177].

miR-24, a member of the miR-23b cluster, is highly expressed in U87 GSCs, directly targeting suppression of tumorigenicity 7-like $(S T 7 L)$. miR-24 abrogation allows ST7L restoration, which suppresses $\beta$-catenin/transcription factor 4 (TCF-4) activity, leading to cell cycle arrest at the G0/G1 phase and enhanced apoptosis. The same effect on the $\beta$-catenin/TCF-4 pathway, as well as reduced expression of the downstream CCND1, STAT3 and $c-M Y C$, is obtained by inhibition of miR-27b, another member of the miR-23b cluster, aberrantly upregulated in U87 GSCs [178,179].

miR-30 upregulation has been described as a key factor in the tumorigenicity of GSCs, by silencing suppressor of cytokine signaling 3 (SOCS3) and thereby enhancing the activation of the Janus kinase (JAK)/STAT3 signaling cascade, which sustains GSCs' survival, proliferation, and antagonizes their differentiation. When a miR-30 inhibitor is transfected into U87 GSCs, the JAK/STAT3 signaling is significantly suppressed, as well as STAT3 phosphorylation $[150,180]$.

The major tumor suppressor PTEN has been found to be targeted by several miRNAs, including miR-17-5p, -19a-3p, -19b-3p, belonging to the miR-17-92 cluster, and miR-21-5p, -26, -130b-3p, 
$-221-3 p,-222-3 p,-494-3 p$, which are overexpressed in GSCs. They function as anti-apoptotic miRNAs by inhibiting PTEN and activating the PI3K/AKT signaling pathway as the main involved pathway $[3,132,134,181,182]$.

miR-92b, upregulated in U87 GSCs, directly targets the SMAD family member 3 (SMAD3), a central activator of the TGF- $\beta$ /cyclin-dependent kinase inhibitor $1 \mathrm{~A}\left(\mathrm{CDKN} 1 \mathrm{~A} / \mathrm{P} 21^{\mathrm{CIP} 1}\right.$ ) apoptotic signaling pathway. On the contrary, the silencing of endogenous miR-92b has been reported to increase the expression of $S M A D 3$ and induce overexpression of P21, which halts cell cycle progression and warrants apoptosis [183].

miR-138 overexpression is considered a molecular signature of GSCs, by acting as a pro-survival oncomiR, which regulates multiple genes and pathways simultaneously, including bladder cancer associated protein (BLCAP), CASP3, nerve growth factor-inducible anti-proliferative (BTG2), and tumor suppressor candidate 2 (TUSC2). However, specific depletion of miR-138 in U87 and U251 cell lines can prevent cell survival and the formation of tumor spheres [126,184].

miR-149 overexpression in U87 GSCs has been related to a significant downregulation of caspase-2 (CASP2) expression and a downstream effect on p53 and p21 expression, leading to cell survival and proliferation $[185,186]$.

It has been reported that the level of miR-154 in GBM is elevated and inversely correlated to the expression of its target phosphoribosyl pyrophosphate synthetase 1 (PRPS1), acting as a positive regulator of proliferation in CD133+ GSCs. Conversely, knockdown of miR-154 remarkably suppresses GSCs' proliferation [252].

miR-155 is an oncomiR aberrantly expressed in GSCs that impairs cell differentiation by suppressing caudal-type homeobox 1 protein (CDX1). miR-155 upregulation has been shown to significantly inhibit early and late apoptosis in U87 GSCs, by affecting its downstream target PTEN, the expression of CASP3 and CASP9, and the PI3K/AKT signaling pathway [187]. Similarly, miR-155-3p is overexpressed in U87 GSCs, acting as an oncomiR by targeting the transcription factor sine oculis homeobox 1 (SIX1), promoting cell proliferation and preventing apoptosis. However, introducing a miR-155-3p inhibitor in chemoresistant cells rescues SIX1 expression, and thus induces cell cycle arrest at the G1/S phase and enhances TMZ-induced apoptosis [3,188].

miR-182, a member of a miRNA cluster in chromosomal locus 7q31-34, is frequently described as amplified in A375 melanoma cell lines, acting as an oncomiR through the suppression of transcription factors forkhead box O3 (FOXO3) and microphthalmia-associated transcription factor (MITF). On the contrary, its downregulation triggers apoptosis and blocks invasion [140,189-191].

miR-196a is overexpressed in GSCs, exerting its oncogenic effect by suppression of NFKB inhibitor alpha $(I \kappa B \alpha)$ and consequent upregulation of NF- $\kappa B$ along with related anti-apoptotic proteins. miR-196a-5p acts as anti-apoptotic miRNA by inhibiting the transcription factor forkhead box O1 (FOXO1) as its main target $[3,192,193]$.

miR-204-5p and miR-211-5p have high expression levels in A375 melanoma cells resistant to the B-Raf Proto-Oncogene, Serine/Threonine Kinase (BRAF) inhibitor vemurafenib, compared to parental cells. This overexpression leads to the inhibition of the proapoptotic transcription factor C/EBP homologous protein 10 (CHOP), also known as DNA damage-inducible transcript 3 (DDIT3) and as growth arrest and DNA damage-inducible protein 153 (GADD153), and insulin-like growth factor 2 receptor (IGF-2R), both recognized as miR-211-5p targets, and determines pro-survival cell responses in A375 cells [194,195].

miR-210 expression is elevated in GSCs, particularly in response to hypoxia conditions, in which it targets several genes such as MAX network transcriptional repressor (MNT). Knockdown of miR-210, by a specific antisense sequence, rescues the expression of $M N T$; thus, strongly prompting apoptosis, differentiation, and G0/G1 cell cycle arrest in hypoxic GSCs $[3,186,196]$. Moreover, miR-210 depletion causes a reduction in HIF1 $\alpha$ protein expression, most likely due to the disruption of a hypoxia-induced positive feedback loop between HIF1 $\alpha$ and miR-210, which represses glycerol-3-phosphate dehydrogenase 1-like (GPD1L), responsible for the HIF1 $\alpha$ protein stability $[196,197]$. Regulator of 
differentiation 1 (ROD1) has been described as a further target for miR-210. Indeed, restoring ROD1 expression, by downregulation of miR-210 in U87 and U251 GSCs, inhibits cell proliferation and induces apoptosis [198].

miR-221 and -222 are upregulated in GSCs, both repressing apoptosis and prompting cell cycle progression by directly targeting the cell growth-suppressive $P 27^{K I P 1}$ and cyclin-dependent kinase inhibitor 1C (CDKN1C/P57 KIP2) genes [132,199,253]. Furthermore, miR-221/222 cluster overexpression has been reported to unset apoptosis in GSCs by targeting p53-upregulated modulator of apoptosis (PUMA), which is not able to bind Bcl-2 and Bcl-2-like protein 1 (Bcl-x) anymore $[200,201]$. In this context, treatment of U87 and U251 GSCs with antisense oligonucleotides for miR-221/222 leads to cell cycle arrest in the G0/G1 phase as well as to enhanced sensitivity to radiotherapy and to TMZ, by regulating apoptosis independently of p53 status [199,201,202].

miR-221 and -222 have also been reported to be upregulated in A375 melanoma stem-like cells, resulting in reduced levels of their target V-Kit Hardy-Zuckerman 4 feline sarcoma viral oncogene (C-KIT/CD117), a melanocytic functional player with tumor-suppressive activity via apoptosis induction, occurring when its kinase activation is silenced [204]. Another proto-oncogene, targeted by miR-222, is V-Ets avian erythroblastosis virus E26 oncogene homolog 1 (ETS-1), involved in the induction of apoptosis [203,205]. Moreover, some studies have shown that miR-221/222 directly target P27, frequently downregulated in melanoma, which serves as a crucial cell cycle regulator through modulation of cyclin D1 [140,206,207].

miR-330, -363, and -582-5p, overexpressed in CD133+ GSCs, have been shown to function as pro-survival oncomiRs by inhibiting cell apoptosis through the silencing of the major performer caspases CASP3, CASP9, and Bcl-2-interacting mediator of cell death (BIM) signaling $[87,208]$.

miR-335 is upregulated in U87 and U251 GSCs, due to amplification of its locus on chromosome 7q32, which confirms that chromosomal abnormalities and/or epigenetic events contribute to miRNA dysregulation. miR-335 function, by targeting the tumor suppressor disheveled-associated activator of morphogenesis 1 (DAAM1) and the transcription factor paired box 6 (PAX6), results in a pro-survival effect. Conversely, inhibition of miR-335 can rescue apoptosis and suppress cell growth [209-211].

In the NBL-WS human NB cell line, high expression levels of miR-380-5p have been related to inhibited TP53 and activated Harvey rat sarcoma viral oncogene homolog (HRAS) genes. Conversely, as reported by Li et al. [212], the inhibition of miR-380-5p recovers p53 expression and apoptotic cell death, which implies the enhancing effect of miR-380-5p on neural CSCs [213].

miR-381 is a highly expressed oncomiR, which confers stemness, prompts tumor progression, and induces drug resistance in GBM cells. However, its activity can be suppressed by administration of antisense oligonucleotides, in combination with TMZ treatment [254].

A cluster including 14 miRNAs on the $X$ chromosome, namely miR-506-514 cluster, is consistently overexpressed in A375 melanoma stem-like cells. Conversely, the inhibition of this cluster has been demonstrated to strongly enhance the percentage of apoptotic cells [255].

miR-638 has been shown to be upregulated during melanoma initiation and progression. By the marked reduction in the TP53-inducible nuclear protein 2 (TP53INP2) gene, it can suppress p53-mediated apoptosis pathways in A375 melanoma stem-like cells [214].

There is evidence that miRNAs play a key role in regulating the activation status of the apoptotic Hippo pathway via the post-transcriptional suppression of multiple target mRNAs of Hippo signaling components. Just as an example, the upregulation of miR-130b has been found to inactivate the Hippo pathway and promote CSC characteristics in GBM cells by directly suppressing macrophage stimulating 1/2 (MST1/2) and protein salvador homolog 1 (SAV1). Conversely, inhibition of miR-130b attenuates these effects, enabling the MST1/2-SAV1 kinase complex to activate the Hippo kinase apoptotic cascade [215].

Recent evidence supports the importance of hypoxic conditions in GSCs' maintenance. Restricted oxygen levels have been shown to expand and preserve the fraction of such CSCs, thanks to the expression of both HIF $1 \alpha / \mathrm{HIF} 2 \alpha$ subunits, which regulate the transcription of hundreds of genes 
in response to low levels of oxygen. HIF1 $\alpha$ is a key regulator of CSC proliferation and fate in MB and GBM by activating the NF-KB pathway to sustain CSC survival and tumorigenesis $[150,256,257]$. In U251 GSCs, hypoxia requires Notch pathway activation to drive stemness maintenance [258,259]. The hypoxic niche also protects GSCs by limiting drug penetration and thus contributes to chemotherapy resistance [260]. Hypoxia and the stem-like state have been reported to influence the biogenesis and expression of a set of miRNAs, including miR-7-5p,-21-5p, -23b-3p, -205-5p, -210, and -373. At the same time, the dysregulation of these miRNAs can play a pro-survival role in this microenvironment, sustaining GSC stemness $[3,108,196]$.

\subsection{Pro- and Anti-Apoptotic miRNAs and Their Therapeutic Implication in Tumors}

Current chemo- and radiotherapy treatments may be able to kill the bulk of tumor cells, but spare the relevant fraction of CSCs, which are protected by peculiar niches in the tumor mass and specific resistance mechanisms [261]. Since CSCs are the "seeds" for tumor initiation and development, metastasis, drug resistance, and recurrence, it is more than feasible that the development of therapeutic strategies directed to the CSCs- or CSC-like-subpopulations can be promising, especially if targeting those miRNAs involved in the regulation of CSC biology [150].

Many efforts are being made to knock out CSCs in tumors of neural/neural crest origin. Among the biological features of CSCs useful in the development of anti-CSC therapies, several chemotherapeutic drugs target the components of apoptotic pathways [75]. The balance between cell survival and apoptosis is crucial in CSCs, where the axis survival/cell cycle/apoptosis is dysregulated [114]. Deregulation of miRNAs in CSCs is heavily connected to apoptosis evasion, which leads to enhanced tumorigenesis and drug resistance [76]. Targeting the specific pattern of miRNAs that prevent neural CSCs from proceeding to apoptosis is, thus, emerging as an effective antitumor treatment and an adjuvant to standard therapies. Moreover, eliminating the CSC subpopulation, which survives over the conventional therapies, may improve the tumor management in clinical settings (Table 2).

Recently, it has been shown that HIFs are required for GSC maintenance and resistance to chemotherapy. Specifically, even under modest hypoxic conditions, HIF2 $\alpha$ is elevated in GSCs, while it is not found in NSCs at mRNA or protein level. Hypoxia ensures resistance to TMZ as well, by inducing O6-methylguanine-DNA-methyltransferase (MGMT) expression in GSCs. TMZ treatment indeed has been shown incapable of halting self-renewal of CD133+ GSCs expressing MGMT [108,260]. For this reason, miRNAs modulating HIF expression in the hypoxic niche can offer hope as therapeutic targets in GBM to regulate the hypoxic HIF switch, the hypoxic microenvironment, and the consequent stem cell survival and resistance to therapy.

Therapeutic strategies based on targeting dysregulated miRNAs in CSCs include: the delivery of RNA oligonucleotides (miRNA mimics), designed to mimic endogenous CSC-suppressive miRNAs, downregulated in the CSC subpopulation; the introduction of antisense oligonucleotides (antagomiRs), with the aim to inhibit oncogenic miRNAs with CSC-enhancing function, overexpressed in CSCs; the regulation of CSC-related miRNAs by the administration of synthetic or natural agents. Both miRNA mimics and antagomiRs, thus, can control the expression of multiple genes and restore the signaling pathways leading to CSC death, resulting in a decrease in tumor progression and/or a sensitization to therapy.

Recently, nanotechnology has been applied to the design of lipid-based nanovectors, such as liposomes and lipoplexes, able to deliver chemically engineered sense or antisense oligonucleotides (Figure 1D). Moreover, intravenous delivery of tumor suppressing miRNAs or antagomiRs has been found to significantly induce apoptosis, as well as inhibit cell growth and proliferation in CSCs. Furthermore, a magnet-bead based miRNA delivery system has been developed. This system allows magnetic guidance to the site of interest and enables efficient miRNA delivery with very low cytotoxic effects. Further, exosomes can function as ideal drug carriers for antitumor therapies thanks to the many advantages, including low immunogenicity, biocompatibility, easy production, cytotoxicity, easy storage, high drug loading capacity, and long half-life [150]. 
Table 2. miRNA-based experimental antitumoral therapeutic approaches.

\begin{tabular}{lccc}
\hline \multicolumn{1}{c}{ Therapeutic Agent } & Combined Treatment & Cancer Type & Ref. \\
\hline antagomiR & & & \\
\hline anti-miR-381 & TMZ & GBM & {$[254]$} \\
anti-miR-10b + anti-miR-21 & TMZ & glioma, GBM & {$[262-264]$} \\
anti-miR-21 & Sunitinib & GBM & {$[265]$} \\
anti-miR-21 & Erismodegib & glioma & {$[266,267]$} \\
anti-miR-125b & LY294002 + TMZ & GBM & {$[268]$} \\
\hline miRNA mimics & & & \\
\hline miR-145 & DMC & GBM & {$[126]$} \\
miR-146b-5p & Radiotherapy & glioma & {$[128]$} \\
miR-181a & Radiotherapy & GBM & {$[134]$} \\
miR-211 & Radiotherapy + TMZ & GBM & {$[139]$} \\
let-7 & Phenformin + TMZ/DCA & glioma & {$[269]$} \\
miR-224 & Radiotherapy & GBM & {$[270]$} \\
miR-153 & Radiotherapy & GBM & {$[271]$} \\
miR-146a & Curcumin + TMZ & GBM & {$[272]$} \\
miR-326 & Curcumin & GBM & {$[273]$} \\
\hline Cross-phylum derived miRNAs & & & \\
\hline Shrimp-derived miR-S8, -35-3p, -965 & & melanoma & {$[274-276]$} \\
\hline
\end{tabular}

TMZ: temozolomide; DCA: dichloroacetate; DMC: demethoxycurcumin; GBM: glioblastoma multiforme.

Since the carrying capability is an index of the efficacy of nanomedicine, the design of efficient nanocarriers represents the current challenge necessary to improve the cellular intake and enhance the capability of entering within CSCs [71]. Meanwhile, the synthesis of specific and highly stable sense/antisense oligonucleotides is crucial to avoid off-target effects and to prevent their degradation during the delivery towards the target site, respectively.

At the same time, biotechnology has adopted the potential of RNA interference to knockdown the expression of specific RNAs and this option is being introduced in the clinic as a form of miRNA-based therapy. The advantage of miRNA administration as a cancer therapy is that a single miRNA can influence many pathways simultaneously to amplify its effect and finally achieve clinical benefit [83].

Distinct miRNAs are critical in the control of neural/neural crest-derived CSC survival. Therefore, in the context of a pro-apoptotic treatment, targeting their dysregulated expression to eradicate the tumor CSC population is emerging as a promising approach to cancer therapy. Dysregulation of miRNA expression is a mechanism that confers CSCs the ability to escape from apoptotic signals. Therefore, since apoptosis is the major type of cell death triggered by antitumor treatments [75], defective apoptosis may lead to drug resistance and then treatment failure and tumor relapse. Accordingly, due to their chemo- and radioresistant potential, GSCs, MB- and NB-CSCs, as well as melanoma stem cells, appear to be a powerful cellular target for such antitumor therapeutic regimens.

Specifically, GSC-targeted therapy is becoming a hot spot of recent studies for the treatment of glioma. The knowledge of miRNA expression levels and their correlation with GBM pathogenesis has led to the identification of specific miRNAs in GSCs with potential therapeutic applicability [277-279].

A novel multimodal therapy approach for GBM consists of oncomiR silencing, mediated by tumor-targeted nanoparticles, combined with standard chemo- and radiotherapeutic agents. This strategy has been applied in vitro combining miR-10b and miR-21 silencing with TMZ [262-264], or miR-21 inhibitors with the tyrosine kinase inhibitor sunitinib [265]. Similarly, treatment of glioma initiating cells (GICs) with NPV-LDE-225 (Erismodegib) has been shown to regulate proliferation and apoptosis, by means of the suppression of miR-21 [266,267]. Meanwhile, chemo- and radiotherapy have been reported to be involved in modulating the expression of miRNAs responsible for GBM development. It has been described that, after $48 \mathrm{~h}$ of treatment with TMZ and ionizing radiation, 
GSC neurospheres express higher levels of miR-21 in comparison to attached cells, confirming the crucial role of GSCs in the acquisition of chemo- and radioresistance [280].

Repression of the miR-381/neurofilament light polypeptide (NEFL) axis sensitizes GBM cells to TMZ-induced apoptosis by regulating multidrug resistance factors. Thus, this miRNA may potentially serve as a novel adjuvant therapeutic target for GBM [254].

Delivery of let-7a miRNA to GSCs has been carried out by magnetofection, using zinc-doped $\mathrm{Fe}_{3} \mathrm{O}_{4}$ nanoparticles, which show high cellular uptake (nearly $98 \%$ ) and effective downregulation of the let-7a targets, KRAS and PI3K [281]. Moreover, a combined treatment of GSCs with phenformin and TMZ or dichloroacetate (DCA) succeeds in exerting an enhanced pro-apoptotic effect in vitro, by means of an increased expression and bioavailability of let-7, along with a marked inhibition of its target HMGA2 [269].

Treatment with miR-146b-5p, -181a, -211, and -224 mimics has been demonstrated to increase radiosensitivity of GSCs. Thus, these findings suggest that these miRNAs can provide new rationales for novel combinational therapies, in which they synergistically cooperate with standard treatments designed for GBM patients $[128,134,139,270]$. Moreover, the combination of radiotherapy and miR-153 ectopic expression in GSCs has been demonstrated to enhance the efficiency of glioma treatment [271].

miR-145 has been introduced as a novel therapeutic target for glioma in combination with the curcuminoid drug named demethoxycurcumin (DMC). Indeed, Lenti-GFP-miR-145 pretreatment increases GSC apoptosis induced by DMC, as demonstrated by both terminal deoxynucleotidyl transferase (TdT) dUTP nick- end labeling (TUNEL) cell apoptosis and histone-DNA enzyme-linked immunosorbent assay (ELISA) assays [126].

The exposure to curcumin (diferuloylmethane), a natural compound extracted from turmeric (Curcuma longa Linn.), can lead to upregulation of miR-146a, which significantly silences the transcriptional activity of NF- $\mathrm{KB}$ in U87 GSCs. Thus, TMZ-induced cytotoxicity can be potentiated by the concomitant treatment with curcumin [272].

Treatment with miR-326 mimics exerts a tumor inhibition effect by prompting curcumin-mediated apoptosis, by means of decreasing the activity of the SHH/GLI1 pathway. Considering the GLI1-p53 functional network, increased p53 expression occurs in U87 (p53 wild-type) but not in U251 GSCs (p53 mutant), suggesting that miR-326 and curcumin combinatorial therapy can decrease SHH/GLI1 activity also independently of the 533 status. In addition, the increased miR-326 expression, observed in response to curcumin treatment, underlines the feedback loop between miR-326 and the SHH/GLI1 signaling, providing a mechanism for the enriched anti-glioma effect due to the combined treatment [273]. Taken together, these findings support the suggestion by Klinger et al. about the need for clinical trials with curcumin for the treatment of GBM and other brain tumors [267,282].

The combined treatment with miR-125b inhibitor and PI3K/Akt pathway inhibitor LY294002 has been shown to reverse the chemoresistance of GSCs and then to sensitize these cells to TMZ-induced apoptosis by targeting the $\mathrm{Wnt} / \beta$-catenin signaling pathway $[150,268]$.

An increasing number of studies has shown that elevated levels of distinct oncomiRs, such as miR-10b [169,264,283], -30 [180], -221/222 [284], -335 [285], are associated with poor survival in GBM patients, according to Kaplan-Meier survival curves and referring to The Cancer Genome Atlas (TCGA) data. This is why the modulation of such miRNAs' activity by antisense molecules appears to be a promising therapeutic option.

Within the framework of the development of effective therapies for the treatment of NB, the manipulation of miRNA expression and the induction of apoptosis and differentiation in the CSC subpopulation seem to be the most promising strategies investigated in the last few decades $[80,263,286,287]$.

The resistance of melanoma to conventional therapies is, at least in part, attributed to its CSC population [274]. Thus, targeting specific miRNAs involved in the regulation of the CSC-associated chemo- and radiotherapy-resistant phenotype could be useful for the preferential killing of CSCs, recovering therapy sensitivity. 
In the context of melanoma treatment, novel epigenetic strategies using miRNAs derived from natural food have been proposed. Indeed, the transfection of melanoma stem cells with cross-phylum-derived miRNAs has been demonstrated to be effective in the induction of apoptosis, as well as in the suppression of cell stemness, viability, and proliferation. The shrimp-derived miR-S8 has been described to suppress stemness and tumor progression by degrading the mRNA of the transcription factor human Y-box binding protein 1 (YB-1) in melanoma stem cells [275]. Likely, mja-miR-35-3p, which belongs to the shrimp Marsupenaeus japonicus and possesses antiviral activity in this species, has been demonstrated to induce cell cycle arrest in the G1 phase to boost apoptosis, and to impair the sphere-forming capacity of melanoma stem cells, by suppressing the protein interacting with never in mitosis A1 (PIN1) gene [276]. In the same way, the shrimp miR-965 can suppress the stemness and proliferation of these cells by interacting with the human eukaryotic translation initiation factor 2C 2 (Ago2) protein and suppressing myeloid cell leukemia sequence 1 (Bcl2-related) (MCL1) expression [274]. Taken together, these studies suggest an alternative mechanism of CSC regulation by miRNAs in a cross-species manner, which can represent a promising natural drug in the treatment of CSC-driven tumors.

Overall, clinical trials exploiting miRNAs as therapeutic targets in the treatment of GBM and melanoma have been extensively described by Chakraborty et al. [288] and Rupaimoole and Slack [289], and the updates on following clinical trial phases have been reported by more recent studies [102,290-292].

Targeting of CSCs by all these forms of miRNA modulation has been claimed to be promising for cancer treatment since it could overcome the limitations of conventional non-specific antitumor therapies, such as chemo- and radiotherapy. In this way, in combination with standard therapies, addressing dysregulated miRNAs to eliminate the aggressive and drug-resistant CSC population could effectively inhibit tumor progression, metastasis, recurrence, and therapy resistance to achieve better treatment outcomes. In light of this, refining the knowledge regarding the miRNA expression pattern in CSCs harbored in tumors of neural/neural crest origin will identify novel specific therapeutic targets against these cancers, paving the way for antitumor personalized medicine.

Author Contributions: A.D., G.G., C.M., D.M.: conceptualization, writing-review and editing. All authors have read and agreed to the published version of the manuscript.

Funding: This study was funded by grants from the "Fondo Integrativo per la Ricerca" (FIR), University of Cagliari (Italy) for the cost of publication.

Conflicts of Interest: The authors declare no conflict of interest.

$\begin{array}{ll}\text { Abbreviations } & \\ \text { A } \beta & \text { amyloid } \beta \text {-peptide } \\ \text { ABC } & \text { ATP binding cassette transporter } \\ A B C B 1 & \text { ATP binding cassette subfamily B member 1 } \\ \text { AD } & \text { Alzheimer's disease } \\ A D D 3 & \text { adducin 3 } \\ \text { ADSC } & \text { adipose-derived stem cell } \\ \text { Ago2 } & \text { eukaryotic translation initiation factor 2C 2 } \\ \text { AIS } & \text { acute ischemic stroke } \\ \text { AKT } & \text { serine-threonine protein kinase } \\ \text { ALS } & \text { amyotrophic lateral sclerosis } \\ \text { ApoE } & \text { apolipoprotein E } \\ \text { ASD } & \text { autism spectrum disorder } \\ B A K 1 & \text { Bcl-2 antagonist/killer 1 } \\ B c l-2 & \text { Bcl-2 apoptosis regulator } \\ B C L 2 L 12 & \text { Bcl-2-like protein 12 } \\ B c l-w & \text { Bcl-2-like protein 2 } \\ B c l-x & \text { Bcl-2-like protein 1 }\end{array}$




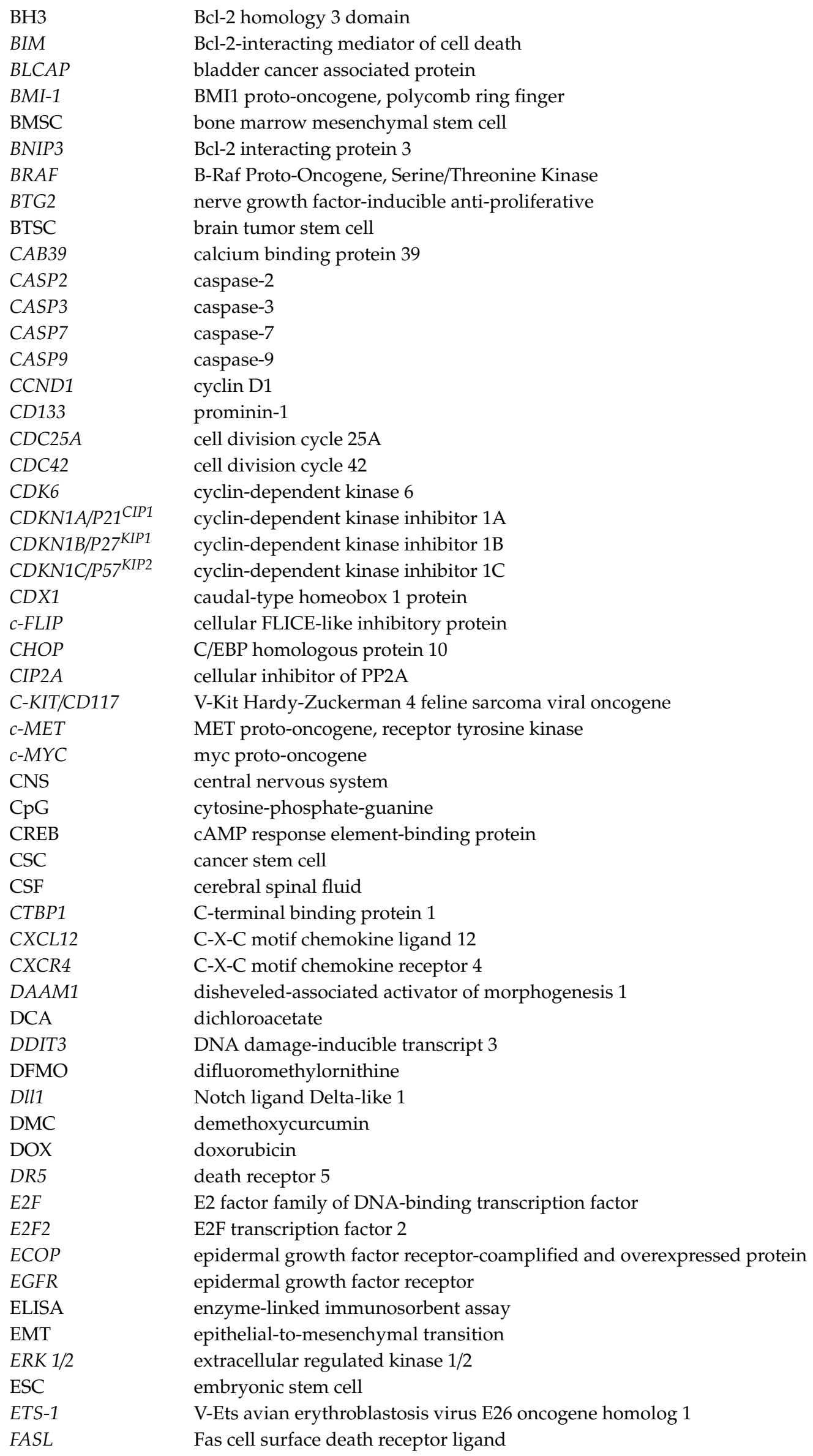




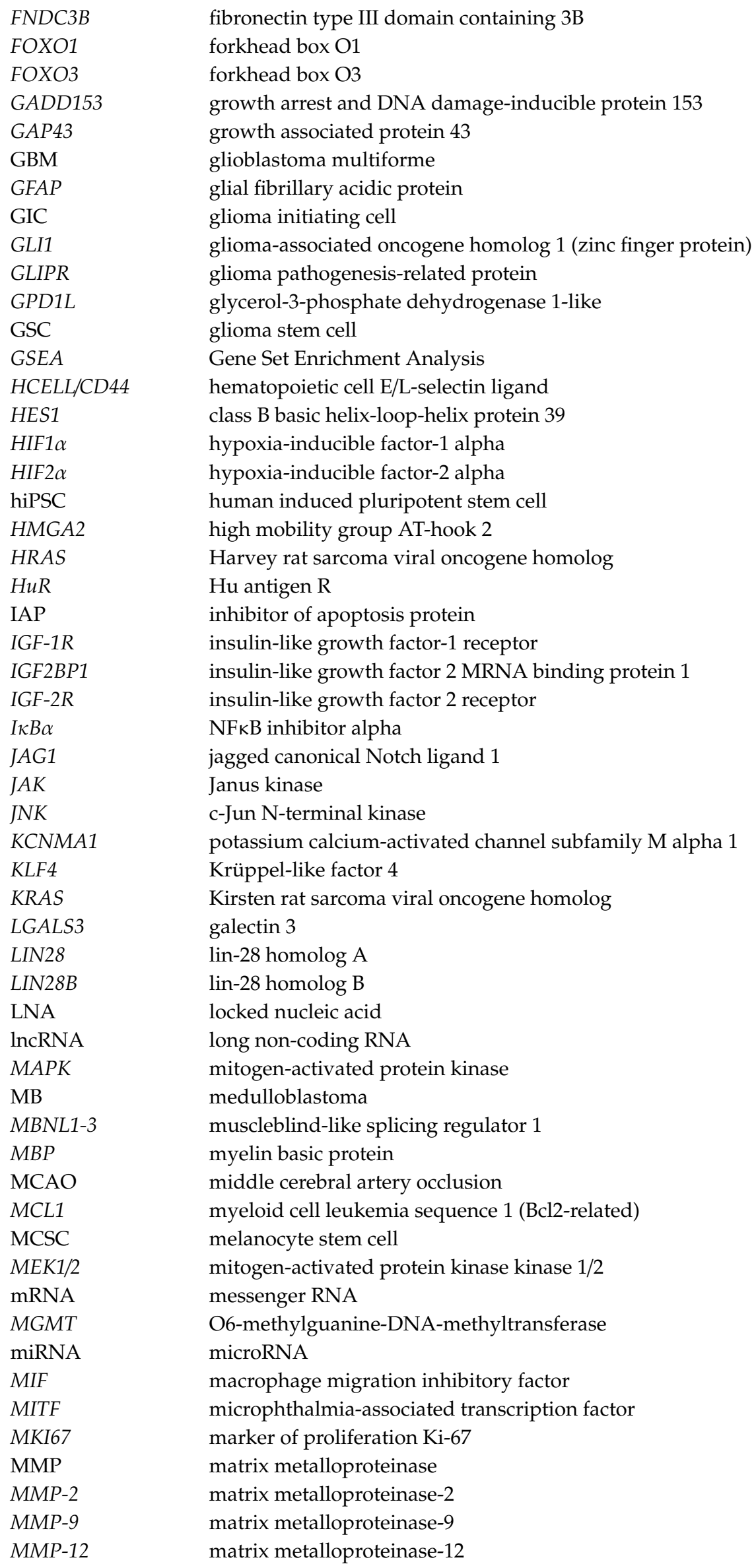




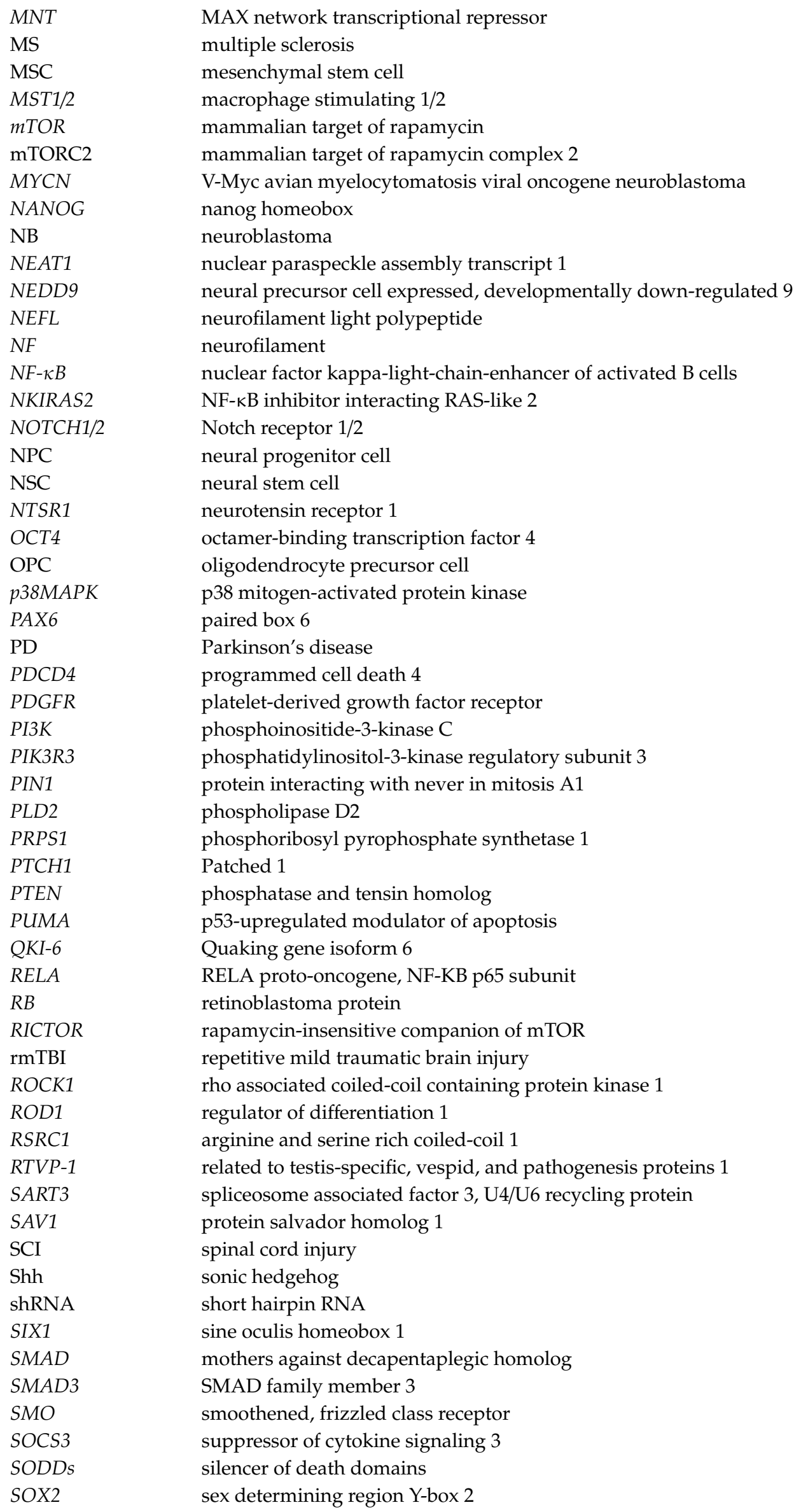




$\begin{array}{ll}\text { SOX9 } & \text { SRY-box transcription factor 9 } \\ \text { SSEA-1/CD15 } & \text { stage specific embryonic antigen 1 } \\ \text { ST7L } & \text { suppression of tumorigenicity 7-like } \\ \text { STAT3 } & \text { signal transducer and activator of transcription 3 } \\ \text { TBI } & \text { traumatic brain injury } \\ \text { TCF-4 } & \text { transcription factor 4 } \\ \text { TCGA } & \text { The Cancer Genome Atlas } \\ \text { TGF- } \beta & \text { transforming growth factor- } \beta \\ \text { TIMP3 } & \text { tissue inhibitor of metalloproteinases 3 } \\ \text { TLR4 } & \text { Toll-like receptor 4 } \\ \text { TMZ } & \text { temozolomide } \\ \text { TNFAIP3 } & \text { tumor necrosis factor alpha-induced protein 3 } \\ \text { TNF } \alpha & \text { tumor necrosis factor alpha } \\ \text { TP53 } & \text { tumor protein p53 } \\ \text { TP53INP2 } & \text { TP53-inducible nuclear protein 2 } \\ \text { TRAIL } & \text { tumor necrosis factor apoptosis inducing ligand } \\ \text { TUNEL } & \text { terminal deoxynucleotidyl transferase (TdT) dUTP nick- end labeling } \\ \text { TUSC2 } & \text { tumor suppressor candidate 2 } \\ \text { Wnt } & \text { wingless-related integration site } \\ \text { WT1 } & \text { Wilms tumor protein 1 } \\ \text { YB-1 } & \text { human Y-box binding protein 1 }\end{array}$

\section{References}

1. Im, H.I.; Kenny, P.J. MicroRNAs in neuronal function and dysfunction. Trends Neurosci. 2012, 35, 325-334. [CrossRef] [PubMed]

2. Hammond, S.M. An overview of microRNAs. Adv. Drug Deliv. Rev. 2015, 87, 3-14. [CrossRef] [PubMed]

3. Diana, A.; Gaido, G.; Murtas, D. MicroRNA Signature in human normal and tumoral neural stem cells. Int. J. Mol. Sci. 2019, 20, 4123. [CrossRef] [PubMed]

4. Banelli, B.; Forlani, A.; Allemanni, G.; Morabito, A.; Pistillo, M.P.; Romani, M. MicroRNA in glioblastoma: An overview. Int. J. Genom. 2017, 2017, 7639084. [CrossRef]

5. Jin, Y.; Wang, J.; Zhang, M.; Zhang, S.; Lei, C.; Chen, H.; Guo, W.; Lan, X. Role of bta-miR-204 in the regulation of adipocyte proliferation, differentiation, and apoptosis. J. Cell Physiol. 2019, 234, 11037-11046. [CrossRef]

6. Su, Z.; Yang, Z.; Xu, Y.; Chen, Y.; Yu, Q. MicroRNAs in apoptosis, autophagy and necroptosis. Oncotarget 2015, 6, 8474-8490. [CrossRef]

7. Su, Y.; Wu, H.; Pavlosky, A.; Zou, L.L.; Deng, X.; Zhang, Z.X.; Jevnikar, A.M. Regulatory non-coding RNA: New instruments in the orchestration of cell death. Cell Death Dis. 2016, 7, e2333. [CrossRef]

8. Pollock, A.; Bian, S.; Zhang, C.; Chen, Z.; Sun, T. Growth of the developing cerebral cortex is controlled by microRNA-7 through the p53 pathway. Cell Rep. 2014, 7, 1184-1196. [CrossRef]

9. de Chevigny, A.; Coré, N.; Follert, P.; Gaudin, M.; Barbry, P.; Béclin, C.; Cremer, H. miR-7a regulation of Pax6 controls spatial origin of forebrain dopaminergic neurons. Nat. Neurosci. 2012, 15, 1120-1126. [CrossRef]

10. Zhao, C.; Sun, G.; Li, S.; Shi, Y.A. Feedback regulatory loop involving microRNA-9 and nuclear receptor TLX in neural stem cell fate determination. Nat. Struct. Mol. Biol. 2009, 16, 365-371. [CrossRef]

11. Shibata, M.; Nakao, H.; Kiyonari, H.; Abe, T.; Aizawa, S. MicroRNA-9 regulates neurogenesis in mouse telencephalon by targeting multiple transcription factors. J. Neurosci. 2011, 31, 3407-3422. [CrossRef] [PubMed]

12. Shibata, M.; Kurokawa, D.; Nakao, H.; Ohmura, T.; Aizawa, S. MicroRNA-9 modulates Cajal-Retzius cell differentiation by suppressing Foxg1 expression in mouse medial pallium. J. Neurosci. 2008, 28, 10415-10421. [CrossRef] [PubMed]

13. Dajas-Bailador, F.; Bonev, B.; Garcez, P.; Stanley, P.; Guillemot, F.; Papalopulu, N. microRNA-9 regulates axon extension and branching by targeting Map1b in mouse cortical neurons. Nat. Neurosci. 2012, 15, 697-699. [CrossRef] [PubMed]

14. Clovis, Y.M.; Enard, W.; Marinaro, F.; Huttner, W.B.; De Pietri Tonelli, D. Convergent repression of Foxp2 3'UTR by miR-9 and miR-132 in embryonic mouse neocortex: Implications for radial migration of neurons. Development 2012, 139, 3332-3342. [CrossRef] [PubMed] 
15. Shu, P.; Wu, C.; Ruan, X.; Liu, W.; Hou, L.; Fu, H.; Wang, M.; Liu, C.; Zeng, Y.; Chen, P.; et al. Opposing gradients of microRNA expression temporally pattern layer formation in the developing neocortex. Dev. Cell 2019, 49, 764-785. [CrossRef] [PubMed]

16. Makeyev, E.V.; Zhang, J.; Carrasco, M.A.; Maniatis, T. The MicroRNA miR-124 promotes neuronal differentiation by triggering brain-specific alternative pre-mRNA splicing. Mol. Cell 2007, 27, 435-448. [CrossRef] [PubMed]

17. Volvert, M.L.; Prévot, P.P.; Close, P.; Laguesse, S.; Pirotte, S.; Hemphill, J.; Rogister, F.; Kruzy, N.; Sacheli, R.; Moonen, G.; et al. MicroRNA targeting of CoREST controls polarization of migrating cortical neurons. Cell Rep. 2014, 7, 1168-1183. [CrossRef]

18. Cheng, L.C.; Pastrana, E.; Tavazoie, M.; Doetsch, F. miR-124 regulates adult neurogenesis in the subventricular zone stem cell niche. Nat. Neurosci. 2009, 12, 399-408. [CrossRef]

19. Szulwach, K.E.; Li, X.; Smrt, R.D.; Li, Y.; Luo, Y.; Lin, L.; Santistevan, N.J.; Li, W.; Zhao, X.; Jin, P. Cross talk between microRNA and epigenetic regulation in adult neurogenesis. J. Cell. Biol. 2010, 189, 127-141. [CrossRef]

20. Sun, G.; Ye, P.; Murai, K.; Lang, M.F.; Li, S.; Zhang, H.; Li, W.; Fu, C.; Yin, J.; Wang, A.; et al. miR-137 forms a regulatory loop with nuclear receptor TLX and LSD1 in neural stem cells. Nat. Commun. 2011, 2, 529. [CrossRef]

21. Chua, C.; Tang, B.L. miR-34a in Neurophysiology and Neuropathology. J. Mol. Neurosci. 2019, 67, $235-246$. [CrossRef] [PubMed]

22. Aranha, M.M.; Santos, D.M.; Xavier, J.M.; Low, W.C.; Steer, C.J.; Solá, S.; Rodrigues, C.M. Apoptosis-associated microRNAs are modulated in mouse, rat and human neural differentiation. BMC Genom. 2010, 11, 514. [CrossRef] [PubMed]

23. Kole, A.J.; Swahari, V.; Hammond, S.M.; Deshmukh, M. miR-29b is activated during neuronal maturation and targets BH3-only genes to restrict apoptosis. Genes Dev. 2011, 25, 125-130. [CrossRef] [PubMed]

24. Wang, F.; Xiong, L.; Huang, X.; Zhao, T.; Wu, L.Y.; Liu, Z.H.; Ding, X.; Liu, S.; Wu, Y.; Zhao, Y.; et al. miR-210 suppresses BNIP3 to protect against the apoptosis of neural progenitor cells. Stem Cell Res. 2013, 11, 657-667. [CrossRef]

25. Konovalova, J.; Gerasymchuk, D.; Parkkinen, I.; Chmielarz, P.; Domanskyi, A. Interplay between microRNAs and oxidative stress in neurodegenerative diseases. Int. J. Mol. Sci. 2019, 20, 6055. [CrossRef]

26. Wei, W.; Wang, Z.Y.; Ma, L.N.; Zhang, T.T.; Cao, Y.; Li, H. MicroRNAs in Alzheimer's disease: Function and potential applications as diagnostic biomarkers. Front. Mol. Neurosci. 2020, 13, 160. [CrossRef]

27. Kou, X.; Chen, D.; Chen, N. The Regulation of microRNAs in Alzheimer's Disease. Front. Neurol. 2020, 11, 288. [CrossRef]

28. Praticò, D. The functional role of microRNAs in the pathogenesis of tauopathy. Cells 2020, 9, 2262. [CrossRef]

29. Wang, L.; Zhang, L. MicroRNAs in amyotrophic lateral sclerosis: From pathogenetic involvement to diagnostic biomarker and therapeutic agent development. Neurol. Sci. 2020, 1-9. [CrossRef]

30. Sadlon, A.; Takousis, P.; Alexopoulos, P.; Evangelou, E.; Prokopenko, I.; Perneczky, R. miRNAs identify shared pathways in Alzheimer's and Parkinson's diseases. Trends Mol. Med. 2019, 25, 662-672. [CrossRef]

31. Doxakis, E. Cell-free microRNAs in Parkinson's disease: Potential biomarkers that provide new insights into disease pathogenesis. Ageing Res. Rev. 2020, 58, 101023. [CrossRef] [PubMed]

32. Ravnik-Glavač, M.; Glavač, D. Circulating RNAs as potential biomarkers in amyotrophic lateral sclerosis. Int. J. Mol. Sci. 2020, 21, 1714. [CrossRef] [PubMed]

33. Martinez, B.; Peplow, P.V. MicroRNAs in blood and cerebrospinal fluid as diagnostic biomarkers of multiple sclerosis and to monitor disease progression. Neural Regen. Res. 2020, 15, 606-619. [CrossRef] [PubMed]

34. Ghafouri-Fard, S.; Taheri, M. A comprehensive review of non-coding RNAs functions in multiple sclerosis. Eur. J. Pharmacol. 2020, 879, 173127. [CrossRef]

35. Atif, H.; Hicks, S.D. A review of MicroRNA biomarkers in traumatic brain injury. J. Exp. Neurosci. 2019, 13, 1179069519832286. [CrossRef]

36. Guedes, V.A.; Devoto, C.; Leete, J.; Sass, D.; Acott, J.D.; Mithani, S.; Gill, J.M. Extracellular vesicle proteins and microRNAs as biomarkers for traumatic brain injury. Front. Neurol. 2020, 11, 663. [CrossRef]

37. Salloum-Asfar, S.; Satheesh, N.J.; Abdulla, S.A. Circulating miRNAs, Small but Promising Biomarkers for Autism Spectrum Disorder. Front. Mol. Neurosci. 2019, 12, 253. [CrossRef] 
38. Wu, X.; Li, W.; Zheng, Y. Recent progress on relevant microRNAs in autism spectrum disorders. Int. J. Mol. Sci. 2020, 21, 5904. [CrossRef]

39. Fauré, J.; Lachenal, G.; Court, M.; Hirrlinger, J.; Chatellard-Causse, C.; Blot, B.; Grange, J.; Schoehn, G.; Goldberg, Y.; Boyer, V.; et al. Exosomes are released by cultured cortical neurones. Mol. Cell. Neurosci. 2006, 31, 642-648. [CrossRef]

40. Lachenal, G.; Pernet-Gallay, K.; Chivet, M.; Hemming, F.J.; Belly, A.; Bodon, G.; Blot, B.; Haase, G.; Goldberg, Y.; Sadoul, R. Release of exosomes from differentiated neurons and its regulation by synaptic glutamatergic activity. Mol. Cell. Neurosci. 2011, 46, 409-418. [CrossRef]

41. Frühbeis, C.; Fröhlich, D.; Kuo, W.P.; Amphornrat, J.; Thilemann, S.; Saab, A.S.; Kirchhoff, F.; Möbius, W.; Goebbels, S.; Nave, K.A.; et al. Neurotransmitter-triggered transfer of exosomes mediates oligodendrocyte-neuron communication. PLoS Biol. 2013, 11, e1001604. [CrossRef] [PubMed]

42. Chivet, M.; Javalet, C.; Laulagnier, K.; Blot, B.; Hemming, F.J.; Sadoul, R. Exosomes secreted by cortical neurons upon glutamatergic synapse activation specifically interact with neurons. J. Extracell. Vesicles 2014, 3, 24722. [CrossRef] [PubMed]

43. Sharma, P.; Mesci, P.; Carromeu, C.; McClatchy, D.R.; Schiapparelli, L.; Yates, J.R., 3rd; Muotri, A.R.; Cline, H.T. Exosomes regulate neurogenesis and circuit assembly. Proc. Natl. Acad. Sci. USA 2019, 116, 16086-16094. [CrossRef]

44. Andjus, P.; Kosanović, M.; Milićević, K.; Gautam, M.; Vainio, S.J.; Jagečić, D.; Kozlova, E.N.; Pivoriūnas, A.; Chachques, J.C.; Sakaj, M.; et al. Extracellular vesicles as innovative tool for diagnosis, regeneration and protection against neurological damage. Int. J. Mol. Sci. 2020, 21, 6859. [CrossRef]

45. Jahangard, Y.; Monfared, H.; Moradi, A.; Zare, M.; Mirnajafi-Zadeh, J.; Mowla, S.J. Therapeutic effects of transplanted exosomes containing miR-29b to a rat model of Alzheimer's disease. Front. Neurosci. 2020, 14, 564. [CrossRef]

46. Marzano, M.; Bejoy, J.; Cheerathodi, M.R.; Sun, L.; York, S.B.; Zhao, J.; Kanekiyo, T.; Bu, G.; Meckes, D.G., Jr.; $\mathrm{Li}, \mathrm{Y}$. Differential effects of extracellular vesicles of lineage-specific human pluripotent stem cells on the cellular behaviors of isogenic cortical spheroids. Cells 2019, 8, 993. [CrossRef]

47. Monni, E.; Congiu, T.; Massa, D.; Nat, R.; Diana, A. Human neurospheres: From stained sections to three-dimensional assembly. Transl. Neurosci. 2011, 2, 43-48. [CrossRef]

48. Massa, D.; Pillai, R.; Monni, E.; Kokaia, Z.; Diana, A. Expression analysis of pluripotency-associated genes in human fetal cortical and striatal neural stem cells during differentiation. Transl. Neurosci. 2012, 3, 242-248. [CrossRef]

49. Pusic, K.M.; Pusic, A.D.; Kraig, R.P. Environmental enrichment stimulates immune cell secretion of exosomes that promote CNS myelination and may regulate inflammation. Cell. Mol. Neurobiol. 2016, 36, 313-325. [CrossRef]

50. Geng, W.; Tang, H.; Luo, S.; Lv, Y.; Liang, D.; Kang, X.; Hong, W. Exosomes from miRNA-126-modified ADSCs promotes functional recovery after stroke in rats by improving neurogenesis and suppressing microglia activation. Am. J. Transl. Res. 2019, 11, 780-792.

51. Xin, H.; Wang, F.; Li, Y.; Lu, Q.E.; Cheung, W.L.; Zhang, Y.; Zhang, Z.G.; Chopp, M. Secondary release of exosomes from astrocytes contributes to the increase in neural plasticity and improvement of functional recovery after stroke in rats treated with exosomes harvested from MicroRNA 133b-overexpressing multipotent mesenchymal stromal cells. Cell Transplant. 2017, 26, 243-257. [CrossRef] [PubMed]

52. Xin, H.; Katakowski, M.; Wang, F.; Qian, J.Y.; Liu, X.S.; Ali, M.M.; Buller, B.; Zhang, Z.G.; Chopp, M. MicroRNA cluster miR-17-92 cluster in exosomes enhance neuroplasticity and functional recovery after stroke in rats. Stroke 2017, 48, 747-753, Erratum in Stroke 2017, 48, e137. [CrossRef] [PubMed]

53. Duan, S.; Wang, F.; Cao, J.; Wang, C. Exosomes derived from microRNA-146a-5p-enriched bone marrow mesenchymal stem cells alleviate intracerebral hemorrhage by inhibiting neuronal apoptosis and microglial m1 polarization. Drug Des. Dev. Ther. 2020, 14, 3143-3158. [CrossRef] [PubMed]

54. Ling, X.; Zhang, G.; Xia, Y.; Zhu, Q.; Zhang, J.; Li, Q.; Niu, X.; Hu, G.; Yang, Y.; Wang, Y.; et al. Exosomes from human urine-derived stem cells enhanced neurogenesis via miR-26a/HDAC6 axis after ischaemic stroke. J. Cell. Mol. Med. 2020, 24, 640-654. [CrossRef] 
55. Huang, S.; Ge, X.; Yu, J.; Han, Z.; Yin, Z.; Li, Y.; Chen, F.; Wang, H.; Zhang, J.; Lei, P. Increased miR-124-3p in microglial exosomes following traumatic brain injury inhibits neuronal inflammation and contributes to neurite outgrowth via their transfer into neurons. FASEB J. 2018, 32, 512-528, Erratum in FASEB J. 2018, 32, 2315. [CrossRef] [PubMed]

56. Yang, Y.; Ye, Y.; Kong, C.; Su, X.; Zhang, X.; Bai, W.; He, X. MiR-124 enriched exosomes promoted the M2 polarization of microglia and enhanced hippocampus neurogenesis after traumatic brain injury by inhibiting TLR4 pathway. Neurochem. Res. 2019, 44, 811-828. [CrossRef]

57. Li, D.; Huang, S.; Yin, Z.; Zhu, J.; Ge, X.; Han, Z.; Tan, J.; Zhang, S.; Zhao, J.; Chen, F.; et al. Increases in miR-124-3p in microglial exosomes confer neuroprotective effects by targeting fip200-mediated neuronal autophagy following traumatic brain injury. Neurochem. Res. 2019, 44, 1903-1923. [CrossRef]

58. Ge, X.; Guo, M.; Hu, T.; Li, W.; Huang, S.; Yin, Z.; Li, Y.; Chen, F.; Zhu, L.; Kang, C.; et al. Increased microglial exosomal miR-124-3p alleviates neurodegeneration and improves cognitive outcome after rmTBI. Mol. Ther. 2020, 28, 503-522. [CrossRef]

59. Kang, J.; Li, Z.; Zhi, Z.; Wang, S.; Xu, G. MiR-21 derived from the exosomes of MSCs regulates the death and differentiation of neurons in patients with spinal cord injury. Gene Ther. 2019, 26, 491-503. [CrossRef]

60. Xu, G.; Ao, R.; Zhi, Z.; Jia, J.; Yu, B. miR-21 and miR-19b delivered by hMSC-derived EVs regulate the apoptosis and differentiation of neurons in patients with spinal cord injury. J. Cell. Physiol. 2019, 234, 10205-10217. [CrossRef]

61. Zhou, X.; Chu, X.; Yuan, H.; Qiu, J.; Zhao, C.; Xin, D.; Li, T.; Ma, W.; Wang, H.; Wang, Z.; et al. Mesenchymal stem cell derived EVs mediate neuroprotection after spinal cord injury in rats via the microRNA-21-5p/FasL gene axis. Biomed. Pharmacother. 2019, 115, 108818. [CrossRef] [PubMed]

62. Li, D.; Zhang, P.; Yao, X.; Li, H.; Shen, H.; Li, X.; Wu, J.; Lu, X. Exosomes derived from miR-133b-modified mesenchymal stem cells promote recovery after spinal cord injury. Front. Neurosci. 2018, 12, 845. [CrossRef] [PubMed]

63. Ren, Z.W.; Zhou, J.G.; Xiong, Z.K.; Zhu, F.Z.; Guo, X.D. Effect of exosomes derived from MiR-133b-modified ADSCs on the recovery of neurological function after SCI. Eur. Rev. Med. Pharmacol. Sci. 2019, 23, 52-60. [CrossRef]

64. Yu, T.; Zhao, C.; Hou, S.; Zhou, W.; Wang, B.; Chen, Y. Exosomes secreted from miRNA-29b-modified mesenchymal stem cells repaired spinal cord injury in rats. Braz. J. Med. Biol. Res. 2019, 52, e8735. [CrossRef]

65. Li, C.; Li, X.; Zhao, B.; Wang, C. Exosomes derived from miR-544-modified mesenchymal stem cells promote recovery after spinal cord injury. Arch. Physiol. Biochem. 2020, 126, 369-375. [CrossRef] [PubMed]

66. Eiriz, M.F.; Malva, J.O.; Agasse, F.; Bernardino, L. Histamine in the neural and cancer stem cell niches. In Stem Cells and Cancer Stem Cells; Hayat, M., Ed.; Springer: Dordrecht, The Netherlands, 2014; Volume 12, pp. 3-17. [CrossRef]

67. Snyder, E.Y.; Stephen Yip, S.; Pernia, C.; Lopez, C.A.; Liu, Y.; Sajti, E. Stem Cell Biology. In Fetal and Neonatal Physiology, 3rd ed.; Polin, R.A., Fox, W.W., Abman, S.H., Rowitch, D.H., Benitz, W.E., Eds.; Elsevier: Philadelphia, PA, USA, 2017; Volume 1, Chapter 6; pp. 54-75.

68. Wigle, J.Y.; Eisenstat, D.E. Common signaling pathways used during development. In The Developing Human, Clinically Oriented Embryology, 11th ed.; Moore, K., Persaud, T.V.N., Torchia, M., Eds.; Elsevier: Philadelphia, PA, USA, 2020; Chapter 21; pp. 463-495.

69. Dirks, P.B. Brain tumor stem cells: The cancer stem cell hypothesis writ large. Mol. Oncol. 2010, 4, 420-430. [CrossRef]

70. Bayin, N.S.; Modrek, A.S.; Placantonakis, D.G. Brain tumor stem cells. In Molecular Pathology of Nervous System Tumors. Biological Stratification and Targeted Therapies; Karajannis, M.A., Zagzag, D., Eds.; Springer: New York, NY, USA, 2015; Chapter 2; pp. 23-34. [CrossRef]

71. Aghajani, M.; Mansoori, B.; Mohammadi, A.; Asadzadeh, Z.; Baradaran, B. New emerging roles of CD133 in cancer stem cell: Signaling pathway and miRNA regulation. J. Cell. Physiol. 2019, 234, 21642-21661. [CrossRef]

72. Piras, F.; Perra, M.T.; Murtas, D.; Minerba, L.; Floris, C.; Maxia, C.; Demurtas, P.; Ugalde, J.; Ribatti, D.; Sirigu, P. Combinations of apoptosis and cell-cycle control biomarkers predict the outcome of human melanoma. Oncol. Rep. 2008, 20, 271-277. [CrossRef] 
73. Pessoa, I.A.; da Silva, F.P.E.; Anselmo, N.P.; de Oliveira, E.H.C. Alterations in TP53 gene-Implications in tumorigenesis. Process and prognosis in central nervous system cancer. In Tumors of the Central Nervous System-Primary and Secondary; Morgan, L.R., Ed.; IntechOpen: London, UK, 2014; Chapter 6; pp. 127-174. [CrossRef]

74. Speciale, A.; Monti, P.; Fronza, G.; Izzotti, A.; Menichini, P. MicroRNA-mutant P53 crosstalk in chemoresistance: A hint to monitor therapy outcome. MicroRNA 2020. Advance online publication. [CrossRef]

75. An, X.; Sarmiento, C.; Tan, T.; Zhu, H. Regulation of multidrug resistance by microRNAs in anti-cancer therapy. Acta Pharm. Sin. B 2017, 7, 38-51. [CrossRef]

76. Safa, A.R. Resistance to cell death and its modulation in cancer stem cells. Crit. Rev. Oncog. 2016, 21, $203-219$. [CrossRef] [PubMed]

77. Ukrainskaya, V.M.; Stepanov, A.V.; Glagoleva, I.S.; Knorre, V.D.; Belogurov, A.A.J.; Gabibov, A.G. Death receptors: New opportunities in cancer therapy. Acta Nat. 2017, 9, 55-63. [CrossRef]

78. Brower, J.V.; Clark, P.A.; Lyon, W.; Kuo, J.S. MicroRNAs in cancer: Glioblastoma and glioblastoma cancer stem cells. Neurochem. Int. 2014, 77, 68-77. [CrossRef] [PubMed]

79. Kumar, D.; Gorain, M.; Kundu, G.; Kundu, G.C. Therapeutic implications of cellular and molecular biology of cancer stem cells in melanoma. Mol. Cancer 2017, 16, 7. [CrossRef] [PubMed]

80. Aravindan, N.; Jain, D.; Somasundaram, D.B.; Herman, T.S.; Aravindan, S. Cancer stem cells in neuroblastoma therapy resistance. Cancer Drug Resist. 2019, 2, 948-967. [CrossRef] [PubMed]

81. Islam, F.; Gopalan, V.; Lam, A.K.Y. Cancer stem cells: Role in tumor progression and treatment resistance. In Oncogenomics. From Basic Research to Precision Medicine; Dammacco, F., Silvestris, F., Eds.; Elsevier: Philadelphia, PA, USA, 2019; Chapter 6; pp. 77-87. [CrossRef]

82. Mens, M.M.J.; Ghanbari, M. Cell cycle regulation of stem cells by microRNAs. Stem Cell Rev. Rep. 2018, 14, 309-322. [CrossRef]

83. Bhere, D.; Tamura, K.; Wakimoto, H.; Choi, S.H.; Purow, B.; Debatisse, J.; Shah, K. microRNA-7 upregulates death receptor 5 and primes resistant brain tumors to caspase-mediated apoptosis. Neuro Oncol. 2018, 20, 215-224. [CrossRef]

84. Geng, J.; Luo, H.; Pu, Y.; Zhou, Z.; Wu, X.; Xu, W.; Yang, Z. Methylation mediated silencing of miR-23b expression and its role in glioma stem cells. Neurosci. Lett. 2012, 528, 185-189. [CrossRef]

85. Reuland, S.N.; Smith, S.M.; Bemis, L.T.; Goldstein, N.B.; Almeida, A.R.; Partyka, K.A.; Marquez, V.E.; Zhang, Q.; Norris, D.A.; Shellman, Y.G. MicroRNA-26a is strongly downregulated in melanoma and induces cell death through repression of silencer of death domains (SODD). J. Investig. Dermatol. 2013, 133, 1286-1293. [CrossRef]

86. Qian, H.; Yang, C.; Yang, Y. MicroRNA-26a inhibits the growth and invasiveness of malignant melanoma and directly targets on MITF gene. Cell Death Discov. 2017, 3, 17028. [CrossRef]

87. Valdés-Rives, S.A.; Casique-Aguirre, D.; Germán-Castelán, L.; Velasco-Velázquez, M.A.; González-Arenas, A. Apoptotic signaling pathways in glioblastoma and therapeutic implications. Biomed. Res. Int. 2017, 2017, 7403747. [CrossRef] [PubMed]

88. Yang, L.; Li, N.; Yan, Z.; Li, C.; Zhao, Z. MiR-29a-mediated CD133 expression contributes to cisplatin resistance in CD133+ glioblastoma stem cells. J. Mol. Neurosci. 2018, 66, 369-377. [CrossRef] [PubMed]

89. Rokavec, M.; Li, H.; Jiang, L.; Hermeking, H. The p53/miR-34 axis in development and disease. J. Mol. Cell Biol. 2014, 6, 214-230. [CrossRef] [PubMed]

90. de Antonellis, P.; Medaglia, C.; Cusanelli, E.; Andolfo, I.; Liguori, L.; De Vita, G.; Carotenuto, M.; Bello, A.; Formiggini, F.; Galeone, A.; et al. MiR-34a targeting of Notch ligand delta-like 1 impairs CD15+/CD133+ tumor-propagating cells and supports neural differentiation in medulloblastoma. PLoS ONE 2011, 6, e24584. [CrossRef] [PubMed]

91. Guessous, F.; Zhang, Y.; Kofman, A.; Catania, A.; Li, Y.; Schiff, D.; Purow, B.; Abounader, R. MicroRNA-34a is tumor suppressive in brain tumors and glioma stem cells. Cell Cycle 2010, 9, 1031-1036. [CrossRef]

92. Sun, L.; Wu, Z.; Shao, Y.; Pu, Y.; Miu, W.; Yao, J.; Wu, Y.; Yang, Z. MicroRNA-34a suppresses cell proliferation and induces apoptosis in U87 glioma stem cells. Technol. Cancer Res. Treat. 2012, 11, 483-490. [CrossRef]

93. Si, W.; Shen, J.; Zheng, H.; Fan, W. The role and mechanisms of action of microRNAs in cancer drug resistance. Clin. Epigenetics 2019, 11, 25. [CrossRef]

94. Prokopi, M.; Kousparou, C.A.; Epenetos, A.A. The Secret Role of microRNAs in cancer stem cell development and potential therapy: A notch-pathway approach. Front. Oncol. 2015, 4, 389. [CrossRef] 
95. Lodygin, D.; Tarasov, V.; Epanchintsev, A.; Berking, C.; Knyazeva, T.; Körner, H.; Knyazev, P.; Diebold, J.; Hermeking, H. Inactivation of miR-34a by aberrant CpG methylation in multiple types of cancer. Cell Cycle (Georget. Tex.) 2008, 7, 2591-2600. [CrossRef]

96. Chen, L.; Chen, X.R.; Chen, F.F.; Liu, Y.; Li, P.; Zhang, R.; Yan, K.; Yi, Y.J.; Xu, Z.M.; Jiang, X.D. MicroRNA-107 inhibits U87 glioma stem cells growth and invasion. Cell. Mol. Neurobiol. 2013, 33, 651-657. [CrossRef]

97. Silber, J.; Lim, D.A.; Petritsch, C.; Persson, A.I.; Maunakea, A.K.; Yu, M.; Vandenberg, S.R.; Ginzinger, D.G.; James, C.D.; Costello, J.F.; et al. miR-124 and miR-137 inhibit proliferation of glioblastoma multiforme cells and induce differentiation of brain tumor stem cells. BMC Med. 2008, 6, 14. [CrossRef] [PubMed]

98. Meza-Sosa, K.F.; Pedraza-Alva, G.; Pérez-Martínez, L. microRNAs: Key triggers of neuronal cell fate. Front. Cell. Neurosci. 2014, 8, 175. [CrossRef] [PubMed]

99. Bier, A.; Giladi, N.; Kronfeld, N.; Lee, H.K.; Cazacu, S.; Finniss, S.; Xiang, C.; Poisson, L.; de Carvalho, A.C.; Slavin, S.; et al. MicroRNA-137 is downregulated in glioblastoma and inhibits the stemness of glioma stem cells by targeting RTVP-1. Oncotarget 2013, 4, 665-676. [CrossRef]

100. Deng, Y.; Deng, H.; Bi, F.; Liu, J.; Bemis, L.T.; Norris, D.; Wang, X.J.; Zhang, Q. MicroRNA-137 targets carboxyl-terminal binding protein 1 in melanoma cell lines. Int. J. Biol. Sci. 2011, 7, 133-137. [CrossRef] [PubMed]

101. Qi, J.; Wang, W.W.; Chen, W.; Lu, W.Y.; Shang, A.Q. Mechanism of miR-137 regulating migration and invasion of melanoma cells by targeting PIK3R3 gene. J. Cell. Biochem. 2018. [CrossRef] [PubMed]

102. Varrone, F.; Caputo, E. The miRNAs Role in Melanoma and in Its Resistance to Therapy. Int. J. Mol. Sci. 2020, 21, 878. [CrossRef] [PubMed]

103. Zhang, Z.; Zhang, S.; Ma, P.; Jing, Y.; Peng, H.; Gao, W.Q.; Zhuang, G. Lin28B promotes melanoma growth by mediating a microRNA regulatory circuit. Carcinogenesis 2015, 36, 937-945. [CrossRef]

104. Afrang, N.; Imani, M.; Honardoost, M. Melanoma and Associated MicroRNAs. J. Skin Stem Cell 2016, 3, e63854. [CrossRef]

105. Garg, N.; Vijayakumar, T.; Bakhshinyan, D.; Venugopal, C.; Singh, S.K. MicroRNA regulation of brain tumour initiating cells in central nervous system tumours. Stem Cells Int. 2015, 2015, 141793. [CrossRef]

106. Shi, L.; Zhang, J.; Pan, T.; Zhou, J.; Gong, W.; Liu, N.; Fu, Z.; You, Y. MiR-125b is critical for the suppression of human U251 glioma stem cell proliferation. Brain Res. 2010, 1312, 120-126. [CrossRef]

107. Zhao, B.; Bian, E.B.; Li, J.; Li, J. New advances of microRNAs in glioma stem cells, with special emphasis on aberrant methylation of microRNAs. J. Cell. Physiol. 2014, 229, 1141-1147. [CrossRef] [PubMed]

108. Macharia, L.W.; Wanjiru, C.M.; Mureithi, M.W.; Pereira, C.M.; Ferrer, V.P.; Moura-Neto, V. MicroRNAs, hypoxia and the stem-like state as contributors to cancer aggressiveness. Front. Genet. 2019, 10, 125. [CrossRef] [PubMed]

109. Haemmig, S.; Baumgartner, U.; Glück, A.; Zbinden, S.; Tschan, M.P.; Kappeler, A.; Mariani, L.; Vajtai, I.; Vassella, E. miR-125b controls apoptosis and temozolomide resistance by targeting TNFAIP3 and NKIRAS2 in glioblastomas. Cell Death Dis. 2014, 5, e1279. [CrossRef] [PubMed]

110. Chen, J.; Fu, X.; Wan, Y.; Wang, Z.; Jiang, D.; Shi, L. miR-125b inhibitor enhance the chemosensitivity of glioblastoma stem cells to temozolomide by targeting Bak1. Tumour Biol. 2014, 35, 6293-6302. [CrossRef]

111. Wang, Y.; Zeng, G.; Jiang, Y. The emerging roles of miR-125b in cancers. Cancer Manag. Res. 2020, 12, 1079-1088. [CrossRef]

112. Cortez, M.A.; Bueso-Ramos, C.; Ferdin, J.; Lopez-Berestein, G.; Sood, A.K.; Calin, G.A. MicroRNAs in body fluids-the mix of hormones and biomarkers. Nat. Rev. Clin. Oncol. 2011, 8, 467-477. [CrossRef]

113. Le, M.T.; Teh, C.; Shyh-Chang, N.; Xie, H.; Zhou, B.; Korzh, V.; Lodish, H.F.; Lim, B. MicroRNA-125b is a novel negative regulator of p53. Genes Dev. 2009, 23, 862-876. [CrossRef]

114. Rambow, F.; Bechadergue, A.; Luciani, F.; Gros, G.; Domingues, M.; Bonaventure, J.; Meurice, G.; Marine, J.C.; Larue, L. Regulation of Melanoma Progression through the TCF4/miR-125b/NEDD9 Cascade. J. Investig. Dermatol. 2016, 136, 1229-1237. [CrossRef]

115. Wozniak, M. microRNA in the control of stem-like phenotype of cancer cells. Cent. Eur. J. Biol. 2013, 8, 931-942. [CrossRef]

116. Godlewski, J.; Nowicki, M.O.; Bronisz, A.; Williams, S.; Otsuki, A.; Nuovo, G.; Raychaudhury, A.; Newton, H.B.; Chiocca, E.A.; Lawler, S. Targeting of the Bmi-1 oncogene/stem cell renewal factor by microRNA-128 inhibits glioma proliferation and self-renewal. Cancer Res. 2008, 68, 9125-9130. [CrossRef] 
117. Fang, Y.; Zhang, L.; Li, Z.; Li, Y.; Huang, C.; Lu, X. MicroRNAs in DNA damage response, carcinogenesis, and chemoresistance. In International Review of Cell and Molecular Biology. MiRNAs in Differentiation and Development, 1st ed.; Galluzzi, L., Vitale, I., Eds.; Academic Press (Elsevier): Cambridge, MA, USA, 2017; Volume 333, pp. 1-49. [CrossRef]

118. Gao, X.; Jin, W. The emerging role of tumor-suppressive microRNA-218 in targeting glioblastoma stemness. Cancer Lett. 2014, 353, 25-31. [CrossRef] [PubMed]

119. Zhang, J.M.; Sun, C.Y.; Yu, S.Z.; Wang, Q.; An, T.L.; Li, Y.Y.; Kong, Y.L.; Wen, Y.J. Relationship between miR-218 and $C D K 6$ expression and their biological impact on glioma cell proliferation and apoptosis. Zhonghua Bing Li Xue Za Zhi 2011, 40, 454-459. [PubMed]

120. Xia, H.; Yan, Y.; Hu, M.; Wang, Y.; Wang, Y.; Dai, Y.; Chen, J.; Di, G.; Chen, X.; Jiang, X. MiR-218 sensitizes glioma cells to apoptosis and inhibits tumorigenicity by regulating ECOP-mediated suppression of NF- $\mathrm{kB}$ activity. Neuro Oncol. 2013, 15, 413-422. [CrossRef]

121. Xu, H.; Hu, Y.; Qiu, W. Potential mechanisms of microRNA-129-5p in inhibiting cell processes including viability, proliferation, migration and invasiveness of glioblastoma cells U87 through targeting FNDC3B. Biomed. Pharmacother. 2017, 87, 405-411. [CrossRef]

122. Niu, C.S.; Yang, Y.; Cheng, C.D. MiR-134 regulates the proliferation and invasion of glioblastoma cells by reducing Nanog expression. Int. J. Oncol. 2013, 42, 1533-1540. [CrossRef]

123. Qiu, H.; Chen, F.; Chen, M. MicroRNA-138 negatively regulates the hypoxia-inducible factor $1 \alpha$ to suppress melanoma growth and metastasis. Biol. Open 2019, 8, bio042937. [CrossRef]

124. Gao, X.; Zhu, X.; Sun, Y.; Liu, J. MicroRNA-141 inhibits the self-renewal of glioblastoma stem cells via Jagged1. Mol. Med. Rep. 2017, 16, 167-173. [CrossRef]

125. Du, Y.; Li, J.; Xu, T.; Zhou, D.D.; Zhang, L.; Wang, X. MicroRNA-145 induces apoptosis of glioma cells by targeting BNIP3 and Notch signaling. Oncotarget 2017, 8, 61510-61527. [CrossRef]

126. Qian, C.; Wang, B.; Zou, Y.; Zhang, Y.; Hu, X.; Sun, W.; Xiao, H.; Liu, H.; Shi, L. MicroRNA 145 enhances chemosensitivity of glioblastoma stem cells to demethoxycurcumin. Cancer Manag. Res. 2019, 11, 6829-6840. [CrossRef]

127. Rani, S.B.; Rathod, S.S.; Karthik, S.; Kaur, N.; Muzumdar, D.; Shiras, A.S. MiR-145 functions as a tumor-suppressive RNA by targeting Sox9 and adducin 3 in human glioma cells. Neuro Oncol. 2013, 15, 1302-1316. [CrossRef]

128. Yang, W.; Yu, H.; Shen, Y.; Liu, Y.; Yang, Z.; Sun, T. MiR-146b-5p overexpression attenuates stemness and radioresistance of glioma stem cells by targeting HuR/lincRNA-p21/ $\beta$-catenin pathway. Oncotarget 2016, 7, 41505-41526. [CrossRef] [PubMed]

129. Mao, F.; Zhang, J.; Cheng, X.; Xu, Q. miR-149 inhibits cell proliferation and enhances chemosensitivity by targeting CDC42 and BCL2 in neuroblastoma. Cancer Cell Int. 2019, 19, 357. [CrossRef] [PubMed]

130. Zhao, S.; Deng, Y.; Liu, Y.; Chen, X.; Yang, G.; Mu, Y.; Zhang, D.; Kang, J.; Wu, Z. MicroRNA-153 is tumor suppressive in glioblastoma stem cells. Mol. Biol. Rep. 2013, 40, 2789-2798. [CrossRef] [PubMed]

131. Ma, J.; Yao, Y.; Wang, P.; Liu, Y.; Zhao, L.; Li, Z.; Li, Z.; Xue, Y. MiR-152 functions as a tumor suppressor in glioblastoma stem cells by targeting Krüppel-like factor 4. Cancer Lett. 2014, 355, 85-95. [CrossRef]

132. Sasayama, T.; Tanaka, K.; Kohmura, E. The roles of microRNAs in glioblastoma biology and biomarker. In Neurooncology-Newer Developments; Agrawal, A., Ed.; IntechOpen: London, UK, 2016; Chapter 2; pp. $27-66$. [CrossRef]

133. Huang, S.X.; Zhao, Z.Y.; Weng, G.H.; He, X.Y.; Wu, C.J.; Fu, C.Y.; Sui, Z.Y.; Ma, Y.S.; Liu, T. Upregulation of miR-181a suppresses the formation of glioblastoma stem cells by targeting the Notch2 oncogene and correlates with good prognosis in patients with glioblastoma multiforme. Biochem. Biophys. Res. Commun. 2017, 486, 1129-1136. [CrossRef]

134. González-Gómez, P.; Sánchez, P.; Mira, H. MicroRNAs as regulators of neural stem cell-related pathways in glioblastoma multiforme. Mol. Neurobiol. 2011, 44, 235-249. [CrossRef]

135. Kouri, F.M.; Hurley, L.A.; Daniel, W.L.; Day, E.S.; Hua, Y.; Hao, L.; Peng, C.Y.; Merkel, T.J.; Queisser, M.A.; Ritner, C.; et al. miR-182 integrates apoptosis, growth, and differentiation programs in glioblastoma. Genes Dev. 2015, 29, 732-745. [CrossRef]

136. Matarredona, E.R.; Pastor, A.M. Neural stem cells of the subventricular zone as the origin of human glioblastoma stem cells. Therapeutic implications. Front. Oncol. 2019, 9, 779. [CrossRef] 
137. Zhao, C.; Ma, Z.G.; Mou, S.L.; Yang, Y.X.; Zhang, Y.H.; Yao, W.C. Targeting effect of microRNA on CD133 and its impact analysis on proliferation and invasion of glioma cells. Genet. Mol. Res. 2017, 16. [CrossRef]

138. Deng, Y.; Zhu, G.; Luo, H.; Zhao, S. MicroRNA-203 as a stemness inhibitor of glioblastoma stem cells. Mol. Cells 2016, 39, 619-624. [CrossRef]

139. Asuthkar, S.; Velpula, K.K.; Chetty, C.; Gorantla, B.; Rao, J.S. Epigenetic regulation of miRNA-211 by MMP-9 governs glioma cell apoptosis, chemosensitivity and radiosensitivity. Oncotarget 2012, 3, 1439-1454. [CrossRef]

140. Aftab, M.N.; Dinger, M.E.; Perera, R.J. The role of microRNAs and long non-coding RNAs in the pathology, diagnosis, and management of melanoma. Arch. Biochem. Biophys. 2014, 563, 60-70. [CrossRef] [PubMed]

141. Mazar, J.; DeYoung, K.; Khaitan, D.; Meister, E.; Almodovar, A.; Goydos, J.; Ray, A.; Perera, R.J. The regulation of miRNA-211 expression and its role in melanoma cell invasiveness. PLoS ONE 2010, 5, e13779. [CrossRef] [PubMed]

142. Levy, C.; Khaled, M.; Iliopoulos, D.; Janas, M.M.; Schubert, S.; Pinner, S.; Chen, P.H.; Li, S.; Fletcher, A.L.; Yokoyama, S.; et al. Intronic miR-211 assumes the tumor suppressive function of its host gene in melanoma. Mol. Cell. 2010, 40, 841-849. [CrossRef] [PubMed]

143. Margue, C.; Philippidou, D.; Reinsbach, S.E.; Schmitt, M.; Behrmann, I.; Kreis, S. New target genes of MITF-induced microRNA-211 contribute to melanoma cell invasion. PLoS ONE 2013, 8, e73473. [CrossRef] [PubMed]

144. Wei, Y.; Du, Y.; Chen, X.; Li, P.; Wang, Y.; Zang, W.; Zhao, L.; Li, Z.; Zhao, G. Expression patterns of microRNA-218 and its potential functions by targeting CIP2A and BMI1 genes in melanoma. Tumor. Biol. 2014, 35, 8007-8015. [CrossRef] [PubMed]

145. Long, J.; Menggen, Q.; Wuren, Q.; Shi, Q.; Pi, X. MiR-219-5p inhibits the growth and metastasis of malignant melanoma by targeting BCL-2. BioMed Res. Int. 2017, 2017, 9032502. [CrossRef]

146. Fareh, M.; Turchi, L.; Virolle, V.; Debruyne, D.; Almairac, F.; de-la-Forest Divonne, S.; Paquis, P.; Preynat-Seauve, O.; Krause, K.H.; Chneiweiss, H.; et al. The miR 302-367 cluster drastically affects self-renewal and infiltration properties of glioma-initiating cells through CXCR4 repression and consequent disruption of the SHH-GLI-NANOG network. Cell Death Differ. 2012, 19, 232-244. [CrossRef]

147. Kefas, B.; Comeau, L.; Floyd, D.H.; Seleverstov, O.; Godlewski, J.; Schmittgen, T.; Jiang, J.; diPierro, C.G.; Li, Y.; Chiocca, E.A.; et al. The neuronal microRNA miR-326 acts in a feedback loop with notch and has therapeutic potential against brain tumors. J. Neurosci. 2009, 29, 15161-15168. [CrossRef]

148. Du, W.; Liu, X.; Chen, L.; Dou, Z.; Lei, X.; Chang, L.; Cai, J.; Cui, Y.; Yang, D.; Sun, Y.; et al. Targeting the SMO oncogene by miR-326 inhibits glioma biological behaviors and stemness. Neuro Oncol. 2015, 17, $243-253$. [CrossRef]

149. Miele, E.; Po, A.; Begalli, F.; Antonucci, L.; Mastronuzzi, A.; Marras, C.E.; Carai, A.; Cucchi, D.; Abballe, L.; Besharat, Z.M.; et al. $\beta$-arrestin1-mediated acetylation of Gli1 regulates Hedgehog/Gli signaling and modulates self-renewal of SHH medulloblastoma cancer stem cells. BMC Cancer 2017, 17, 488. [CrossRef] [PubMed]

150. Yang, L.; Shi, P.; Zhao, G.; Xu, J.; Peng, W.; Zhang, J.; Zhang, G.; Wang, X.; Dong, Z.; Chen, F.; et al. Targeting cancer stem cell pathways for cancer therapy. Signal Transduct. Target. Ther. 2020, 5, 8. [CrossRef] [PubMed]

151. Huang, D.; Qiu, S.; Ge, R.; He, L.; Li, M.; Li, Y.; Peng, Y. miR-340 suppresses glioblastoma multiforme. Oncotarget 2015, 6, 9257-9270. [CrossRef] [PubMed]

152. Nan, Y.; Han, L.; Zhang, A.; Wang, G.; Jia, Z.; Yang, Y.; Yue, X.; Pu, P.; Zhong, Y.; Kang, C. MiRNA-451 plays a role as tumor suppressor in human glioma cells. Brain Res. 2010, 1359, 14-21. [CrossRef] [PubMed]

153. Gal, H.; Pandi, G.; Kanner, A.A.; Ram, Z.; Lithwick-Yanai, G.; Amariglio, N.; Rechavi, G.; Givol, D. MIR-451 and Imatinib mesylate inhibit tumor growth of Glioblastoma stem cells. Biochem. Biophys. Res. Commun. 2008, 376, 86-90. [CrossRef]

154. Tian, Y.; Nan, Y.; Han, L.; Zhang, A.; Wang, G.; Jia, Z.; Hao, J.; Pu, P.; Zhong, Y.; Kang, C. MicroRNA miR-451 downregulates the PI3K/AKT pathway through CAB39 in human glioma. Int. J. Oncol 2012, 40, 1105-1112. [CrossRef]

155. Zhang, Y.; Chen, X.; Lian, H.; Liu, J.; Zhou, B.; Han, S.; Peng, B.; Yin, J.; Liu, W.; He, X. MicroRNA-503 acts as a tumor suppressor in glioblastoma for multiple antitumor effects by targeting IGF-1R. Oncol. Rep. 2014, 31, 1445-1452. [CrossRef] 
156. Wang, Z.; Xue, Y.; Wang, P.; Zhu, J.; Ma, J. MiR-608 inhibits the migration and invasion of glioma stem cells by targeting macrophage migration inhibitory factor. Oncol. Rep. 2016, 35, 2733-2742. [CrossRef]

157. Fang, W.; Fan, Y.; Fa, Z.; Xu, J.; Yu, H.; Li, P.; Gu, J. microRNA-625 inhibits tumorigenicity by suppressing proliferation, migration and invasion in malignant melanoma. Oncotarget 2017, 8, 13253-13263. [CrossRef]

158. Wang, R.J.; Li, J.W.; Bao, B.H.; Wu, H.C.; Du, Z.H.; Su, J.L.; Zhang, M.H.; Liang, H.Q. MicroRNA-873 (miRNA-873) inhibits glioblastoma tumorigenesis and metastasis by suppressing the expression of IGF2BP1. J. Biol. Chem. 2015, 290, 8938-8948. [CrossRef]

159. Wang, Y.; Hu, X.; Greshock, J.; Shen, L.; Yang, X.; Shao, Z.; Liang, S.; Tanyi, J.L.; Sood, A.K.; Zhang, L. Genomic DNA copy-number alterations of the let-7 family in human cancers. PLoS ONE 2012, 7, e44399. [CrossRef] [PubMed]

160. Gong, W.; Zheng, J.; Liu, X.; Ma, J.; Liu, Y.; Xue, Y. Knockdown of NEAT1 restrained the malignant progression of glioma stem cells by activating microRNA let-7e. Oncotarget 2016, 7, 62208-62223. [CrossRef] [PubMed]

161. Po, A.; Abballe, L.; Sabato, C.; Gianno, F.; Chiacchiarini, M.; Catanzaro, G.; De Smaele, E.; Giangaspero, F.; Ferretti, E.; Miele, E.; et al. Sonic Hedgehog medulloblastoma cancer stem cells mirnome and transcriptome highlight novel functional networks. Int. J. Mol. Sci. 2018, 19, 2326. [CrossRef] [PubMed]

162. Chirshev, E.; Oberg, K.C.; Ioffe, Y.J.; Unternaehrer, J.J. Let-7 as biomarker, prognostic indicator, and therapy for precision medicine in cancer. Clin. Transl. Med. 2019, 8, 24. [CrossRef]

163. Bahmad, H.F.; Chamaa, F.; Assi, S.; Chalhoub, R.M.; Abou-Antoun, T.; Abou-Kheir, W. Cancer stem cells in neuroblastoma: Expanding the therapeutic frontier. Front. Mol. Neurosci. 2019, 12, 131. [CrossRef]

164. Lozier, A.M.; Rich, M.E.; Grawe, A.P.; Peck, A.S.; Zhao, P.; Chang, A.T.; Bond, J.P.; Sholler, G.S. Targeting ornithine decarboxylase reverses the LIN28/Let-7 axis and inhibits glycolytic metabolism in neuroblastoma. Oncotarget 2015, 6, 196-206. [CrossRef]

165. Coolen, M.; Katz, S.; Bally-Cuif, L. miR-9: A versatile regulator of neurogenesis. Front. Cell. Neurosci. 2013, 7, 220. [CrossRef]

166. Ali Hosseini Rad, S.M.; Bavarsad, M.S.; Arefian, E.; Jaseb, K.; Shahjahani, M.; Saki, N. The role of micrornas in stemness of cancer stem cells. Oncol. Rev. 2013, 7, e8. [CrossRef]

167. Munoz, J.L.; Rodriguez-Cruz, V.; Rameshwar, P. High expression of miR-9 in CD133+ glioblastoma cells in chemoresistance to temozolomide. J. Cancer Stem Cell Res. 2015, 3, e1003. [CrossRef]

168. Jeon, H.M.; Sohn, Y.W.; Oh, S.Y.; Kim, S.H.; Beck, S.; Kim, S.; Kim, H. ID4 imparts chemoresistance and cancer stemness to glioma cells by derepressing miR-9*-mediated suppression of SOX2. Cancer Res. 2011, 71, 3410-3421. [CrossRef]

169. Guessous, F.; Alvarado-Velez, M.; Marcinkiewicz, L.; Zhang, Y.; Kim, J.; Heister, S.; Kefas, B.; Godlewski, J.; Schiff, D.; Purow, B.; et al. Oncogenic effects of miR-10b in glioblastoma stem cells. J. Neurooncol. 2013, 112, 153-163. [CrossRef] [PubMed]

170. Teplyuk, N.M.; Uhlmann, E.J.; Gabriely, G.; Volfovsky, N.; Wang, Y.; Teng, J.; Karmali, P.; Marcusson, E.; Peter, M.; Mohan, A.; et al. Therapeutic potential of targeting microRNA-10b in established intracranial glioblastoma: First steps toward the clinic. EMBO Mol. Med. 2016, 8, 268-287. [CrossRef] [PubMed]

171. Gabriely, G.; Wurdinger, T.; Kesari, S.; Esau, C.C.; Burchard, J.; Linsley, P.S.; Krichevsky, A.M. MicroRNA 21 promotes glioma invasion by targeting matrix metalloproteinase regulators. Mol. Cell. Biol. 2008, 28, 5369-5380. [CrossRef]

172. Gaur, A.B.; Holbeck, S.L.; Colburn, N.H.; Israel, M.A. Downregulation of Pdcd4 by mir-21 facilitates glioblastoma proliferation in vivo. Neuro Oncol. 2011, 13, 580-590. [CrossRef] [PubMed]

173. Wang, G.; Wang, J.J.; Tang, H.M.; To, S.S. Targeting strategies on miRNA-21 and PDCD4 for glioblastoma. Arch. Biochem. Biophys. 2015, 580, 64-74. [CrossRef]

174. Sekar, D.; Krishnan, R.; Panagal, M.; Sivakumar, P.; Gopinath, V.; Basam, V. Deciphering the role of microRNA 21 in cancer stem cells (CSCs). Genes Dis. 2016, 3, 277-281. [CrossRef]

175. Gaziel-Sovran, A.; Segura, M.F.; Di Micco, R.; Collins, M.K.; Hanniford, D.; Vega-Saenz de Miera, E.; Rakus, J.F.; Dankert, J.F.; Shang, S.; Kerbel, R.S.; et al. miR-30b/30d regulation of GalNAc transferases enhances invasion and immunosuppression during metastasis. Cancer Cell 2011, 20, 104-118. [CrossRef]

176. Jiang, L.; Lv, X.; Li, J.; Li, J.; Li, X.; Li, W.; Li, Y. The status of microRNA-21 expression and its clinical significance in human cutaneous malignant melanoma. Acta Histochem. 2012, 114, 582-588. [CrossRef] 
177. Martin del Campo, S.E.; Latchana, N.; Levine, K.M.; Grignol, V.P.; Fairchild, E.T.; Jaime-Ramirez, A.C.; Dao, T.V.; Karpa, V.I.; Carson, M.; Ganju, A. MiR-21 enhances melanoma invasiveness via inhibition of tissue inhibitor of metalloproteinases 3 expression: In vivo effects of MiR-21 inhibitor. PLoS ONE 2015, 10, e0115919. [CrossRef]

178. Chen, L.; Zhang, A.; Li, Y.; Zhang, K.; Han, L.; Du, W.; Yan, W.; Li, R.; Wang, Y.; Wang, K.; et al. MiR-24 regulates the proliferation and invasion of glioma by ST7L via $\beta$-catenin/Tcf-4 signaling. Cancer Lett. 2013, 329, 174-180. [CrossRef]

179. Chen, L.; Li, H.; Han, L.; Zhang, K.; Wang, G.; Wang, Y.; Liu, Y.; Zheng, Y.; Jiang, T.; Pu, P.; et al. Expression and function of miR-27b in human glioma. Oncol. Rep. 2011, 26, 1617-1621. [CrossRef] [PubMed]

180. Che, S.; Sun, T.; Wang, J.; Jiao, Y.; Wang, C.; Meng, Q.; Qi, W.; Yan, Z. miR-30 overexpression promotes glioma stem cells by regulating Jak/STAT3 signaling pathway. Tumour Biol. 2015, 36, 6805-6811. [CrossRef] [PubMed]

181. Li, X.T.; Wang, H.Z.; Wu, Z.W.; Yang, T.Q.; Zhao, Z.H.; Chen, G.L.; Xie, X.S.; Li, B.; Wei, Y.X.; Huang, Y.L.; et al. miR-494-3p Regulates cellular proliferation, invasion, migration, and apoptosis by PTEN/AKT signaling in human glioblastoma cells. Cell. Mol. Neurobiol. 2015, 35, 679-687. [CrossRef] [PubMed]

182. Wang, Z.F.; Liao, F.; Wu, H.; Dai, J. Glioma stem cells-derived exosomal miR-26a promotes angiogenesis of microvessel endothelial cells in glioma. J. Exp. Clin. Cancer Res. 2019, 38, 201. [CrossRef]

183. Wu, Z.B.; Cai, L.; Lin, S.J.; Lu, J.L.; Yao, Y.; Zhou, L.F. The miR-92b functions as a potential oncogene by targeting on Smad3 in glioblastomas. Brain Res. 2013, 1529, 16-25. [CrossRef]

184. Sampath, P. miR-138: A prosurvival oncomiR for glioma stem cells and its therapeutic implications. Future Neurol. 2013, 8, 119-121. [CrossRef]

185. Shen, X.; Li, J.; Liao, W.; Wang, J.; Chen, H.; Yao, Y.; Liu, H.; Ding, K. microRNA-149 targets caspase-2 in glioma progression. Oncotarget 2016, 7, 26388-26399. [CrossRef]

186. Shirjang, S.; Mansoori, B.; Asghari, S.; Duijf, P.; Mohammadi, A.; Gjerstorff, M.; Baradaran, B. MicroRNAs in cancer cell death pathways: Apoptosis and necroptosis. Free Radic. Biol. Med. 2019, 139, 1-15. [CrossRef]

187. Wu, D.; Wang, C. miR-155 regulates the proliferation of glioma cells through PI3K/AKT signaling. Front. Neurol. 2020, 11, 297. [CrossRef]

188. Chen, G.; Chen, Z.; Zhao, H. MicroRNA-155-3p promotes glioma progression and temozolomide resistance by targeting Six1. J. Cell. Mol. Med. 2020, 24, 5363-5374. [CrossRef]

189. Segura, M.F.; Hanniford, D.; Menendez, S.; Reavie, L.; Zou, X.; Alvarez-Diaz, S.; Zakrzewski, J.; Blochin, E.; Rose, A.; Bogunovic, D.; et al. Aberrant miR-182 expression promotes melanoma metastasis by repressing FOXO3 and microphthalmia-associated transcription factor. Proc. Natl. Acad. Sci. USA 2009, 106, 1814-1819. [CrossRef]

190. Liu, S.; Howell, P.M.; Riker, A.I. Up-regulation of miR-182 expression after epigenetic modulation of human melanoma cells. Ann. Surg. Oncol. 2013, 20, 1745-1752. [CrossRef]

191. Gajos-Michniewicz, A.; Czyz, M. Role of miRNAs in Melanoma Metastasis. Cancers 2019, 11, 326. [CrossRef] [PubMed]

192. Yang, G.; Han, D.; Chen, X.; Zhang, D.; Wang, L.; Shi, C.; Zhang, W.; Li, C.; Chen, X.; Liu, H.; et al. MiR-196a exerts its oncogenic effect in glioblastoma multiforme by inhibition of $\mathrm{I}_{\kappa} \mathrm{B} \alpha$ both in vitro and in vivo. Neuro Oncol. 2014, 16, 652-661. [CrossRef]

193. Zhao, X.; Liu, Y.; Zheng, J.; Liu, X.; Chen, J.; Liu, L.; Wang, P.; Xue, Y. GAS5 suppresses malignancy of human glioma stem cells via a miR-196a-5p/FOXO1 feedback loop. Biochim. Biophys. Acta Mol. Cell. Res. 2017, 1864, 1605-1617. [CrossRef] [PubMed]

194. Díaz-Martínez, M.; Benito-Jardón, L.; Alonso, L.; Koetz-Ploch, L.; Hernando, E.; Teixidó, J. miR-204-5p and miR-211-5p contribute to BRAF inhibitor resistance in melanoma. Cancer Res. 2018, 78, 1017-1030. [CrossRef] [PubMed]

195. Motti, M.L.; Minopoli, M.; Di Carluccio, G.; Ascierto, P.A.; Carriero, M.V. MicroRNAs as key players in melanoma cell resistance to MAPK and immune checkpoint inhibitors. Int. J. Mol. Sci. 2020, 21, 4544. [CrossRef] [PubMed]

196. Yang, W.; Wei, J.; Guo, T.; Shen, Y.; Liu, F. Knockdown of miR-210 decreases hypoxic glioma stem cells stemness and radioresistance. Exp. Cell Res. 2014, 326, 22-35. [CrossRef]

197. Bavelloni, A.; Ramazzotti, G.; Poli, A.; Piazzi, M.; Focaccia, E.; Blalock, W.; Faenza, I. MiRNA-210: A current overview. Anticancer Res. 2017, 37, 6511-6521. [CrossRef] 
198. Zhang, S.; Lai, N.; Liao, K.; Sun, J.; Lin, Y. MicroRNA-210 regulates cell proliferation and apoptosis by targeting regulator of differentiation 1 in glioblastoma cells. Folia Neuropathol. 2015, 53, 236-244. [CrossRef]

199. Medina, R.; Zaidi, S.K.; Liu, C.G.; Stein, J.L.; van Wijnen, A.J.; Croce, C.M.; Stein, G.S. MicroRNAs 221 and 222 bypass quiescence and compromise cell survival. Cancer Res. 2008, 68, 2773-2780. [CrossRef] [PubMed]

200. Zhang, C.Z.; Zhang, J.X.; Zhang, A.L.; Shi, Z.D.; Han, L.; Jia, Z.F.; Yang, W.D.; Wang, G.X.; Jiang, T.; You, Y.P.; et al. MiR-221 and miR-222 target PUMA to induce cell survival in glioblastoma. Mol. Cancer 2010, 9, 229. [CrossRef] [PubMed]

201. Chen, L.; Zhang, J.; Han, L.; Zhang, A.; Zhang, C.; Zheng, Y.; Jiang, T.; Pu, P.; Jiang, C.; Kang, C. Downregulation of miR-221/222 sensitizes glioma cells to temozolomide by regulating apoptosis independently of p53 status. Oncol. Rep. 2012, 27, 854-860. [CrossRef] [PubMed]

202. Zhang, C.; Kang, C.; You, Y.; Pu, P.; Yang, W.; Zhao, P.; Wang, G.; Zhang, A.; Jia, Z.; Han, L.; et al. Co-suppression of miR-221/222 cluster suppresses human glioma cell growth by targeting $p 27$ kip1 in vitro and in vivo. Int. J. Oncol. 2009, 34, 1653-1660. [CrossRef] [PubMed]

203. Errico, M.C. Melanoma Stem-Like Cells and Melanoma Cell liNes: Main Molecular Pathways and Possible Microrna Involvement. Ph.D. Thesis, University of Catania, Catania, Italy, 2010.

204. Wang, H.; Boussouar, A.; Mazelin, L.; Tauszig-Delamasure, S.; Sun, Y.; Goldschneider, D.; Paradisi, A.; Mehlen, P. The proto-oncogene c-Kit inhibits tumor growth by behaving as a dependence receptor. Mol. Cell 2018, 72, 413-425. [CrossRef]

205. Gajos-Michniewicz, A.; Duechler, M.; Czyz, M. MiRNA in melanoma-derived exosomes. Cancer Lett. 2014, 347, 29-37. [CrossRef]

206. Felicetti, F.; Errico, M.C.; Bottero, L.; Segnalini, P.; Stoppacciaro, A.; Biffoni, M.; Felli, N.; Mattia, G.; Petrini, M.; Colombo, M.P.; et al. The promyelocytic leukemia zinc finger-microRNA-221/-222 pathway controls melanoma progression through multiple oncogenic mechanisms. Cancer Res. 2008, 68, 2745-2754. [CrossRef]

207. Mirzaei, H.; Gholamin, S.; Shahidsales, S.; Sahebkar, A.; Jaafari, M.R.; Mirzaei, H.R.; Hassanian, S.M.; Avan, A. MicroRNAs as potential diagnostic and prognostic biomarkers in melanoma. Eur. J. Cancer 2016, 53, $25-32$. [CrossRef]

208. Floyd, D.H.; Zhang, Y.; Dey, B.K.; Kefas, B.; Breit, H.; Marks, K.; Dutta, A.; Herold-Mende, C.; Synowitz, M.; Glass, R.; et al. Novel anti-apoptotic microRNAs 582-5p and 363 promote human glioblastoma stem cell survival via direct inhibition of caspase 3, caspase 9, and Bim. PLoS ONE 2014, 9, e96239. [CrossRef]

209. Shu, M.; Zheng, X.; Wu, S.; Lu, H.; Leng, T.; Zhu, W.; Zhou, Y.; Ou, Y.; Lin, X.; Lin, Y.; et al. Targeting oncogenic miR-335 inhibits growth and invasion of malignant astrocytoma cells. Mol. Cancer 2011, 10, 59. [CrossRef]

210. Cheng, Q.; Cao, H.; Chen, Z.; Ma, Z.; Wan, X.; Peng, R.; Jiang, B. PAX6, a novel target of miR-335, inhibits cell proliferation and invasion in glioma cells. Mol. Med. Rep. 2014, 10, 399-404. [CrossRef] [PubMed]

211. Shea, A.; Harish, V.; Afzal, Z.; Chijioke, J.; Kedir, H.; Dusmatova, S.; Roy, A.; Ramalinga, M.; Harris, B.; Blancato, J.; et al. MicroRNAs in glioblastoma multiforme pathogenesis and therapeutics. Cancer Med. 2016, 5, 1917-1946. [CrossRef] [PubMed]

212. Li, Y.; Kong, D.; Ahmad, A.; Bao, B.; Sarkar, F.H. miRNAs in cancer stem cells. In MicroRNA in Regenerative Medicine; Sen, C.K., Ed.; Academic Press (Elsevier): London, UK, 2015; Chapter 5; pp. 137-161.

213. Swarbrick, A.; Woods, S.L.; Shaw, A.; Balakrishnan, A.; Phua, Y.; Nguyen, A.; Chanthery, Y.; Lim, L.; Ashton, L.J.; Judson, R.L.; et al. miR-380-5p represses p53 to control cellular survival and is associated with poor outcome in MYCN-amplified neuroblastoma. Nat. Med. 2010, 16, 1134-1140. [CrossRef] [PubMed]

214. Bhattacharya, A.; Schmitz, U.; Raatz, Y.; Schönherr, M.; Kottek, T.; Schauer, M.; Franz, S.; Saalbach, A.; Anderegg, U.; Wolkenhauer, O.; et al. miR-638 promotes melanoma metastasis and protects melanoma cells from apoptosis and autophagy. Oncotarget 2015, 6, 2966-2980. [CrossRef]

215. Zhu, G.; Wang, Y.; Mijiti, M.; Wang, Z.; Wu, P.F.; Jiafu, D. Upregulation of miR-130b enhances stem cell-like phenotype in glioblastoma by inactivating the Hippo signaling pathway. Biochem. Biophys. Res. Commun. 2015, 465, 194-199. [CrossRef]

216. Chang, T.C.; Wentzel, E.A.; Kent, O.A.; Ramachandran, K.; Mullendore, M.; Lee, K.H.; Feldmann, G.; Yamakuchi, M.; Ferlito, M.; Lowenstein, C.J.; et al. Transactivation of miR-34a by p53 broadly influences gene expression and promotes apoptosis. Mol. Cell. 2007, 26, 745-752. [CrossRef] 
217. Bommer, G.T.; Gerin, I.; Feng, Y.; Kaczorowski, A.J.; Kuick, R.; Love, R.E.; Zhai, Y.; Giordano, T.J.; Qin, Z.S.; Moore, B.B.; et al. p53-mediated activation of miRNA34 candidate tumor-suppressor genes. Curr. Biol. 2007, 17, 1298-1307. [CrossRef]

218. Okada, N.; Lin, C.P.; Ribeiro, M.C.; Biton, A.; Lai, G.; He, X.; Bu, P.; Vogel, H.; Jablons, D.M.; Keller, A.C.; et al. A positive feedback between p53 and miR-34miRNAs mediates tumor suppression. Genes Dev. 2014, 28, 438-450. [CrossRef]

219. Rathod, S.S.; Rani, S.B.; Khan, M.; Muzumdar, D.; Shiras, A. Tumor suppressive miRNA-34a suppresses cell proliferation and tumor growth of glioma stem cells by targeting Akt and Wnt signaling pathways. FEBS Open Bio 2014, 4, 485-495. [CrossRef]

220. Kawamura, Y.; Takouda, J.; Yoshimoto, K.; Nakashima, K. New aspects of glioblastoma multiforme revealed by similarities between neural and glioblastoma stem cells. Cell. Biol. Toxicol. 2018, 34, 425-440. [CrossRef]

221. Yao, M.; Li, S.; Wu, X.; Diao, S.; Zhang, G.; He, H.; Bian, L.; Lu, Y. Cellular origin of glioblastoma and its implication in precision therapy. Cell. Mol. Immunol. 2018, 15, 737-739. [CrossRef] [PubMed]

222. Gimple, R.C.; Bhargava, S.; Dixit, D.; Rich, J.N. Glioblastoma stem cells: Lessons from the tumor hierarchy in a lethal cancer. Genes Dev. 2019, 33, 591-609. [CrossRef] [PubMed]

223. Genovesi, L.A.; Carter, K.W.; Gottardo, N.G.; Giles, K.M.; Dallas, P.B. Integrated analysis of miRNA and mRNA expression in childhood medulloblastoma compared with neural stem cells. PLoS ONE 2011, 6, e23935. [CrossRef] [PubMed]

224. Andolfo, I.; Liguori, L.; De Antonellis, P.; Cusanelli, E.; Marinaro, F.; Pistollato, F.; Garzia, L.; De Vita, G.; Petrosino, G.; Accordi, B.; et al. The micro-RNA 199b-5p regulatory circuit involves Hes1, CD15, and epigenetic modifications in medulloblastoma. Neuro Oncol. 2012, 14, 596-612. [CrossRef] [PubMed]

225. Azzarelli, R.; Simons, B.D.; Philpott, A. The developmental origin of brain tumours: A cellular and molecular framework. Development 2018, 145, dev162693. [CrossRef]

226. Agnihotri, S.; Munoz, D.; Zadeh, G.; Guha, A. Brain tumor-initiating cells and cells of origin in glioblastoma. Transl. Neurosci. 2011, 2, 331-338. [CrossRef]

227. Sun, X.; Jiao, X.; Pestell, T.G.; Fan, C.; Qin, S.; Mirabelli, E.; Ren, H.; Pestell, R.G. MicroRNAs and cancer stem cells: The sword and the shield. Oncogene 2014, 33, 4967-4977. [CrossRef]

228. Kong, D.S. Cancer stem cells in brain tumors and their lineage hierarchy. Int. J. Stem Cells 2012, 5, 12-15. [CrossRef]

229. Ahmed, A.U.; Auffinger, B.; Lesniak, M.S. Understanding glioma stem cells: Rationale, clinical relevance and therapeutic strategies. Expert Rev. Neurother. 2013, 13, 545-555. [CrossRef]

230. Lathia, J.D.; Mack, S.C.; Mulkearns-Hubert, E.E.; Valentim, C.L.; Rich, J.N. Cancer stem cells in glioblastoma. Genes Dev. 2015, 29, 1203-1217. [CrossRef]

231. Godlewski, J.; Ferrer-Luna, R.; Rooj, A.K.; Mineo, M.; Ricklefs, F.; Takeda, Y.S.; Nowicki, M.O.; Salińska, E.; Nakano, I.; Lee, H.; et al. MicroRNA signatures and molecular subtypes of glioblastoma: The role of extracellular transfer. Stem Cell Rep. 2017, 8, 1497-1505. [CrossRef]

232. Nakagawara, A.; Li, Y.; Izumi, H.; Muramori, K.; Inada, H.; Nishi, M. Neuroblastoma. Jpn. J. Clin. Oncol. 2018, 48, 214-241. [CrossRef] [PubMed]

233. Buhagiar, A.; Ayers, D. Chemoresistance, cancer stem cells, and miRNA influences: The case for neuroblastoma. Anal. Cell. Pathol. (Amst) 2015, 2015, 150634. [CrossRef] [PubMed]

234. Veschi, V.; Verona, F.; Thiele, C.J. Cancer stem cells and neuroblastoma: Characteristics and therapeutic targeting options. Front. Endocrinol. (Lausanne) 2019, 10, 782. [CrossRef] [PubMed]

235. Zage, P.E.; Whittle, S.B.; Shohet, J.M. CD114: A new member of the neural crest-derived cancer stem cell marker family. J. Cell. Biochem. 2017, 118, 221-231. [CrossRef] [PubMed]

236. Moon, H.; Donahue, L.R.; Choi, E.; Scumpia, P.O.; Lowry, W.E.; Grenier, J.K.; Zhu, J.; White, A.C. Melanocyte Stem Cell Activation and Translocation Initiate Cutaneous Melanoma in Response to UV Exposure. Cell Stem Cell 2017, 21, 665-678. [CrossRef] [PubMed]

237. Murtas, D.; Pilloni, L.; Diana, A.; Casula, L.; Tomei, S.; Piras, F.; Ferreli, C.; Maxia, C.; Perra, M.T. Tyrosinase and nestin immunohistochemical expression in melanocytic nevi as a histopathologic pattern to trace melanocyte differentiation and nevogenesis. Histochem. Cell. Biol. 2019, 151, 175-185. [CrossRef]

238. Fang, D.; Nguyen, T.K.; Leishear, K.; Finko, R.; Kulp, A.N.; Hotz, S.; Van Belle, P.A.; Xu, X.; Elder, D.E.; Herlyn, M. A tumorigenic subpopulation with stem cell properties in melanomas. Cancer Res. 2005, 65, 9328-9337. [CrossRef] 
239. Piras, F.; Perra, M.T.; Murtas, D.; Minerba, L.; Floris, C.; Maxia, C.; Demurtas, P.; Ugalde, J.; Ribatti, D.; Sirigu, P. The stem cell marker nestin predicts poor prognosis in human melanoma. Oncol. Rep. 2010, 23, 17-24. [CrossRef]

240. Ramgolam, K.; Lauriol, J.; Lalou, C.; Lauden, L.; Michel, L.; de la Grange, P.; Khatib, A.M.; Aoudjit, F.; Charron, D.; Alcaide-Loridan, C.; et al. Melanoma spheroids grown under neural crest cell conditions are highly plastic migratory/invasive tumor cells endowed with immunomodulator function. PLOS ONE 2011, 6, e18784. [CrossRef]

241. Lin, J.; Zhang, D.; Fan, Y.; Chao, Y.; Chang, J.; Li, N.; Han, L.; Han, C. Regulation of Cancer Stem Cell Self-Renewal by HOXB9 Antagonizes Endoplasmic Reticulum Stress-Induced Melanoma Cell Apoptosis via the miR-765-FOXA2 Axis. J. Investig. Dermatol. 2018, 138, 1609-1619. [CrossRef] [PubMed]

242. Marzagalli, M.; Moretti, R.M.; Messi, E.; Marelli, M.M.; Fontana, F.; Anastasia, A.; Bani, M.R.; Beretta, G.; Limonta, P. Targeting melanoma stem cells with the Vitamin E derivative $\delta$-tocotrienol. Sci. Rep. 2018, 8, 587. [CrossRef] [PubMed]

243. Ross, R.A.; Spengler, B.A.; Domènech, C.; Porubcin, M.; Rettig, W.J.; Biedler, J.L. Human neuroblastoma I-type cells are malignant neural crest stem cells. Cell Growth Differ. 1995, 6, 449-456. [PubMed]

244. Ross, R.A. Cellular Heterogeneity. In Neuroblastoma; Cheung, N.K.V., Cohn, S.L., Eds.; Springer: Berlin/Heidelberg, Germany, 2005; Chapter 6; pp. 55-61. [CrossRef]

245. Masserot, C.; Liu, Q.; Nguyen, E.; Gattolliat, C.H.; Valteau-Couanet, D.; Bénard, J.; Huber, C.; Ségal-Bendirdjian, E. WT1 expression is inversely correlated with MYCN amplification or expression and associated with poor survival in non-MYCN-amplified neuroblastoma. Mol. Oncol. 2016, 10, $240-252$. [CrossRef] [PubMed]

246. Sztiller-Sikorska, M.; Koprowska, K.; Jakubowska, J.; Zalesna, I.; Stasiak, M.; Duechler, M.; Czyz, M.E. Sphere formation and self-renewal capacity of melanoma cells is affected by the microenvironment. Melanoma Res. 2012, 22, 215-224. [CrossRef] [PubMed]

247. Sahranavardfard, P.; Firouzi, J.; Azimi, M.; Khosravani, P.; Heydari, R.; Emami Razavi, A.; Dorraj, M.; Keighobadi, F.; Ebrahimi, M. MicroRNA-203 reinforces stemness properties in melanoma and augments tumorigenesis in vivo. J. Cell. Physiol. 2019, 234, 20193-20205. [CrossRef] [PubMed]

248. Wang, G.; Wang, J.; Zhao, H.; Wang, J.; Tony To, S.S. The role of Myc and let-7a in glioblastoma, glucose metabolism and response to therapy. Arch. Biochem. Biophys. 2015, 580, 84-92. [CrossRef]

249. Molenaar, J.J.; Domingo-Fernández, R.; Ebus, M.E.; Lindner, S.; Koster, J.; Drabek, K.; Mestdagh, P.; van Sluis, P.; Valentijn, L.J.; van Nes, J.; et al. LIN28B induces neuroblastoma and enhances MYCN levels via let-7 suppression. Nat. Genet. 2012, 44, 1199-1206. [CrossRef]

250. Dong, Z.; Lei, Q.; Yang, R.; Zhu, S.; Ke, X.X.; Yang, L.; Cui, H.; Yi, L. Inhibition of neurotensin receptor 1 induces intrinsic apoptosis via let-7a-3p/Bcl-w axis in glioblastoma. Br. J. Cancer 2017, 116, 1572-1584. [CrossRef]

251. Inomistova, M.; Khranovska, N.; Skachkova, O. Role of genetic and epigenetic alterations in pathogenesis of neuroblastoma. In Neuroblastoma, Molecular Mechanisms and Therapeutic Interventions; Ray, S.K., Ed.; Academic Press (Elsevier): London, UK, 2019; Chapter 2; pp. 23-41.

252. Yang, L.; Yan, Z.; Wang, Y.; Ma, W.; Li, C. Down-expression of miR-154 suppresses tumourigenesis in CD133 (+) glioblastoma stem cells. Cell Biochem. Funct. 2016, 34, 404-413. [CrossRef]

253. Gillies, J.K.; Lorimer, I.A. Regulation of p27Kip1 by miRNA 221/222 in glioblastoma. Cell Cycle 2007, 6, 2005-2009. [CrossRef] [PubMed]

254. Wang, Z.; Yang, J.; Xu, G.; Wang, W.; Liu, C.; Yang, H.; Yu, Z.; Lei, Q.; Xiao, L.; Xiong, J.; et al. Targeting miR-381-NEFL axis sensitizes glioblastoma cells to temozolomide by regulating stemness factors and multidrug resistance factors. Oncotarget 2015, 6, 3147-3164. [CrossRef] [PubMed]

255. Streicher, K.L.; Zhu, W.; Lehmann, K.P.; Georgantas, R.W.; Morehouse, C.A.; Brohawn, P.; Carrasco, R.A.; Xiao, Z.; Tice, D.A.; Higgs, B.W.; et al. A novel oncogenic role for the miRNA-506-514 cluster in initiating melanocyte transformation and promoting melanoma growth. Oncogene 2012, 31, 1558-1570. [CrossRef] [PubMed]

256. Heddleston, J.M.; Li, Z.; McLendon, R.E.; Hjelmeland, A.B.; Rich, J.N. The hypoxic microenvironment maintains glioblastoma stem cells and promotes reprogramming towards a cancer stem cell phenotype. Cell Cycle 2009, 8, 3274-3284. [CrossRef] 
257. Méndez, O.; Zavadil, J.; Esencay, M.; Lukyanov, Y.; Santovasi, D.; Wang, S.C.; Newcomb, E.W.; Zagzag, D. Knock down of HIF-1alpha in glioma cells reduces migration in vitro and invasion in vivo and impairs their ability to form tumor spheres. Mol. Cancer 2010, 9, 133. [CrossRef]

258. Heddleston, J.M.; Wu, Q.; Rivera, M.; Minhas, S.; Lathia, J.D.; Sloan, A.E.; Iliopoulos, O.; Hjelmeland, A.B.; Rich, J.N. Hypoxia-induced mixed-lineage leukemia 1 regulates glioma stem cell tumorigenic potential. Cell Death Differ. 2012, 19, 428-439. [CrossRef]

259. Qiang, L.; Wu, T.; Zhang, H.W.; Lu, N.; Hu, R.; Wang, Y.J.; Zhao, L.; Chen, F.H.; Wang, X.T.; You, Q.D.; et al. HIF-1 $\alpha$ is critical for hypoxia-mediated maintenance of glioblastoma stem cells by activating Notch signaling pathway. Cell Death Differ. 2012, 19, 284-294. [CrossRef]

260. Auffinger, B.; Spencer, D.; Pytel, P.; Ahmed, A.U.; Lesniak, M.S. The role of glioma stem cells in chemotherapy resistance and glioblastoma multiforme recurrence. Expert Rev. Neurother. 2015, 15, 741-752. [CrossRef]

261. Casciati, A.; Tanori, M.; Manczak, R.; Saada, S.; Tanno, B.; Giardullo, P.; Porcù, E.; Rampazzo, E.; Persano, L.; Viola, G.; et al. Human medulloblastoma cell lines: Investigating on cancer stem cell-like phenotype. Cancers 2020, 12, 226. [CrossRef]

262. Qian, X.; Ren, Y.; Shi, Z.; Long, L.; Pu, P.; Sheng, J.; Yuan, X.; Kang, C. Sequence-dependent synergistic inhibition of human glioma cell lines by combined temozolomide and miR-21 inhibitor gene therapy. Mol. Pharm. 2012, 9, 2636-2645. [CrossRef]

263. Gambari, R.; Brognara, E.; Spandidos, D.A.; Fabbri, E. Targeting oncomiRNAs and mimicking tumor suppressor miRNAs: New trends in the development of miRNA therapeutic strategies in oncology (Review). Int. J. Oncol. 2016, 49, 5-32. [CrossRef] [PubMed]

264. Malhotra, M.; Sekar, T.V.; Ananta, J.S.; Devulapally, R.; Afjei, R.; Babikir, H.A.; Paulmurugan, R.; Massoud, T.F. Targeted nanoparticle delivery of therapeutic antisense microRNAs presensitizes glioblastoma cells to lower effective doses of temozolomide in vitro and in a mouse model. Oncotarget 2018, 9, 21478-21494. [CrossRef] [PubMed]

265. Costa, P.M.; Cardoso, A.L.; Custódia, C.; Cunha, P.; Pereira de Almeida, L.; Pedroso de Lima, M.C. MiRNA-21 silencing mediated by tumor-targeted nanoparticles combined with sunitinib: A new multimodal gene therapy approach for glioblastoma. J. Control. Release 2015, 207, 31-39. [CrossRef] [PubMed]

266. Fu, J.; Rodova, M.; Nanta, R.; Meeker, D.; Van Veldhuizen, P.J.; Srivastava, R.K.; Shankar, S. NPV-LDE-225 (Erismodegib) inhibits epithelial mesenchymal transition and self-renewal of glioblastoma initiating cells by regulating miR-21, miR-128, and miR-200. Neuro Oncol. 2013, 15, 691-706. [CrossRef]

267. Anthiya, S.; Griveau, A.; Loussouarn, C.; Baril, P.; Garnett, M.; Issartel, J.P.; Garcion, E. MicroRNA-based drugs for brain tumors. Trends Cancer 2018, 4, 222-238. [CrossRef]

268. Shi, L.; Fei, X.; Wang, Z. PI3K inhibitor combined with miR-125b inhibitor sensitize TMZ-induced anti-glioma stem cancer effects through inactivation of Wnt/ $\beta$-catenin signaling pathway. In Vitro Cell. Dev. Biol. Anim. 2015, 51, 1047-1055. [CrossRef]

269. Jiang, W.; Finniss, S.; Cazacu, S.; Xiang, C.; Brodie, Z.; Mikkelsen, T.; Poisson, L.; Shackelford, D.B.; Brodie, C. Repurposing phenformin for the targeting of glioma stem cells and the treatment of glioblastoma. Oncotarget 2016, 7, 56456-56470. [CrossRef]

270. Upraity, S.; Kazi, S.; Padul, V.; Shirsat, N.V. MiR-224 expression increases radiation sensitivity of glioblastoma cells. Biochem. Biophys. Res. Commun. 2014, 448, 225-230. [CrossRef]

271. Bahreyni-Toossi, M.T.; Dolat, E.; Khanbabaei, H.; Zafari, N.; Azimian, H. microRNAs: Potential glioblastoma radiosensitizer by targeting radiation-related molecular pathways. Mutat. Res. 2019, 816, 111679. [CrossRef]

272. Wu, H.; Liu, Q.; Cai, T.; Chen, Y.D.; Wang, Z.F. Induction of microRNA-146a is involved in curcumin-mediated enhancement of temozolomide cytotoxicity against human glioblastoma. Mol. Med. Rep. 2015, 12, 5461-5466. [CrossRef]

273. Yin, S.; Du, W.; Wang, F.; Han, B.; Cui, Y.; Yang, D.; Chen, H.; Liu, D.; Liu, X.; Zhai, X.; et al. MicroRNA-326 sensitizes human glioblastoma cells to curcumin via the SHH/GLI1 signaling pathway. Cancer Biol. Ther. 2018, 19, 260-270. [CrossRef] [PubMed]

274. Wu, W.; Xu, C.; Zhang, X.; Yu, A.; Shu, L. Shrimp miR-965 induced the human melanoma stem-like cell apoptosis and inhibited their stemness by disrupting the MCL-1-ER stress-XBP1 feedback loop in a cross-species manner. Stem Cell Res. Ther. 2020, 11, 248. [CrossRef] [PubMed]

275. Yang, F.; Wei, J.; Zhang, S.; Zhang, X. Shrimp miR-S8 suppresses the stemness of human melanoma stem-like cells by targeting the transcription factor YB-1. Cancer Res. 2017, 77, 5543-5553. [CrossRef] [PubMed] 
276. Zhang, S.; Zhang, X. Shrimp miRNA suppresses the stemness of human cancer stem cells via the PIN1 pathway. FASEB J. 2019, 33, 10767-10779. [CrossRef] [PubMed]

277. Garg, M. Emerging role of microRNAs in cancer stem cells: Implications in cancer therapy. World J. Stem Cells 2015, 7, 1078-1089. [CrossRef] [PubMed]

278. Liu, N.; Tu, Y. Systematic review of microRNAs and its therapeutic potential in glioma. Cancer Transl. Med. 2015, 1, 50-66. [CrossRef]

279. Halle, B.; Thomassen, M.; Venkatesan, R.; Kaimal, V.; Marcusson, E.G.; Munthe, S.; Sørensen, M.D.; Aaberg-Jessen, C.; Jensen, S.S.; Meyer, M.; et al. Shift of microRNA profile upon orthotopic xenografting of glioblastoma spheroid cultures. J. Neurooncol. 2016, 128, 395-404. [CrossRef]

280. Rodrigues, A.R.; Neto, F.S.L.; LourençO, L.G.; Trevisan, F.A.; Cirino, M.L.A.; Nery, B.; Peria, F.M.; Pereira-da-Silva, G.; Tazima, M.F.G.S.; Tirapelli, L.F.; et al. Expression of oncogenic microRNA-21 in neurospheres and attached cells of a glioblastoma cell line increased after treatment with temozolomide and ionizing radiation. Genet. Mol. Res. 2019, 18, gmr18095. [CrossRef]

281. Yin, P.T.; Shah, B.P.; Lee, K.B. Combined magnetic nanoparticle-based microRNA and hyperthermia therapy to enhance apoptosis in brain cancer cells. Small 2014, 10, 4106-4112. [CrossRef]

282. Klinger, N.V.; Mittal, S. Therapeutic potential of curcumin for the treatment of brain tumors. Oxid. Med. Cell. Longev. 2016, 2016, 9324085. [CrossRef]

283. Bertoli, G.; Cava, C.; Castiglioni, I. MicroRNAs: New biomarkers for diagnosis, prognosis, therapy prediction and therapeutic tools for breast cancer. Theranostics 2015, 5, 1122-1143. [CrossRef] [PubMed]

284. Zhang, C.; Zhang, J.; Hao, J.; Shi, Z.; Wang, Y.; Han, L.; Yu, S.; You, Y.; Jiang, T.; Wang, J.; et al. High level of miR-221/222 confers increased cell invasion and poor prognosis in glioma. J. Transl. Med. 2012, 10, 119. [CrossRef] [PubMed]

285. Jiang, J.; Sun, X.; Wang, W.; Jin, X.; Bo, X.; Li, Z.; Bian, A.; Jiu, J.; Wang, X.; Liu, D.; et al. Tumor microRNA-335 expression is associated with poor prognosis in human glioma. Med. Oncol. 2012, 29, 3472-3477. [CrossRef] [PubMed]

286. Chen, Y.; Lian, Y.J.; Ma, Y.Q.; Wu, C.J.; Zheng, Y.K.; Xie, N.C. LncRNA SNHG1 promotes $\alpha$-synuclein aggregation and toxicity by targeting miR-15b-5p to activate SIAH1 in human neuroblastoma SH-SY5Y cells. Neurotoxicology 2018, 68, 212-221. [CrossRef] [PubMed]

287. Aravindan, N.; Subramanian, K.; Somasundaram, D.B.; Herman, T.S.; Aravindan, S. MicroRNAs in neuroblastoma tumorigenesis, therapy resistance, and disease evolution. Cancer Drug Resist. 2019, 2, 1086-1105. [CrossRef] [PubMed]

288. Chakraborty, C.; Sharma, A.R.; Sharma, G.; Doss, C.; Lee, S.S. Therapeutic miRNA and siRNA: Moving from bench to clinic as next generation medicine. Mol. Ther. Nucleic Acids 2017, 8, 132-143. [CrossRef]

289. Rupaimoole, R.; Slack, F.J. MicroRNA therapeutics: Towards a new era for the management of cancer and other diseases. Nat. Rev. Drug Discov. 2017, 16, 203-222. [CrossRef]

290. Hanna, J.; Hossain, G.S.; Kocerha, J. The Potential for microRNA Therapeutics and Clinical Research. Front. Genet. 2019, 10, 478. [CrossRef]

291. Chakraborty, C.; Sharma, A.R.; Sharma, G.; Lee, S.S. Therapeutic advances of miRNAs: A preclinical and clinical update. J. Adv. Res. 2020, in press. [CrossRef]

292. Hong, D.S.; Kang, Y.K.; Borad, M.; Sachdev, J.; Ejadi, S.; Lim, H.Y.; Brenner, A.J.; Park, K.; Lee, J.L.; Kim, T.Y.; et al. Phase 1 study of MRX34, a liposomal miR-34a mimic, in patients with advanced solid tumours. Br. J. Cancer 2020, 122. [CrossRef]

Publisher's Note: MDPI stays neutral with regard to jurisdictional claims in published maps and institutional affiliations.

(C) 2020 by the authors. Licensee MDPI, Basel, Switzerland. This article is an open access article distributed under the terms and conditions of the Creative Commons Attribution (CC BY) license (http://creativecommons.org/licenses/by/4.0/). 